\title{
NEUTRON ACTIVATION TECHNIQUES FOR THE MEASUREMENT OF TRACE METALS IN THE MARINE ENVIRONMENT*
}

D. E. Robertson Battelle

Pacific Northwest Laboratory Richland, Washington 99352

R. Carpenter University of Washington Seattle, WA 98105

This report was prepared as an account of work
sponsored by the United States Government. Neither
the United States nor the United States Atomic Energy
Commission, nor any of their employees, nor any of
their contractors, subcontractors, or their employees,
makes any warranty, express or implied, or assumes any
legal liability or responsibility for the accuracy, com-
pleteness or usefulness of any information, apparatus,
product or process disclosed, or represents that its use
would not infringe privately owned rights.

would not infringe privately owned rights.

September 29,1972

* This paper is based on work performed under United States Atomic Energy Commission Contract AT (45-1)-1830 and $\mathrm{AT}(45-1)-2225-\mathrm{T} 24$, and National Science Foundation Grant No. GX-32974. 


\section{DISCLAIMER}

This report was prepared as an account of work sponsored by an agency of the United States Government. Neither the United States Government nor any agency Thereof, nor any of their employees, makes any warranty, express or implied, or assumes any legal liability or responsibility for the accuracy, completeness, or usefulness of any information, apparatus, product, or process disclosed, or represents that its use would not infringe privately owned rights. Reference herein to any specific commercial product, process, or service by trade name, trademark, manufacturer, or otherwise does not necessarily constitute or imply its endorsement, recommendation, or favoring by the United States Government or any agency thereof. The views and opinions of authors expressed herein do not necessarily state or reflect those of the United States Government or any agency thereof. 


\section{DISCLAIMER}

Portions of this document may be illegible in electronic image products. Images are produced from the best available original document. 
TABLE OF CONTENTS

$\underline{\text { Page }}$

I. Introduction

II. Principles of Neutron Activation Analyses

III. Neutron Irradiation Facilities and Procedures

IV. Sample Preparation

A. Materials and Manipulations

B. Preconcentration and Postirradiation Separations

V. Gamma-Ray spectrometry

Data Handling

VI. Elemental Analyses 13

A. Fresh Waters 13

1. Instrumental Neutron Activation Analysis 13

2. Analysis of Elements Requiring Preconcentration or Postirradiation Separations

B. Sea Water

1. Instrumental Analysis

2. Analysis of Elements Requiring Preconcentration or Postirradiation Separations

C. Marine Organisms

1. Instrumental Analysis

2. Analysis of Elements Requiring Preconcentration or Postirradiation Separations

D. Sediments

1. Instrumental Analysis

2. Analysis of Elements Requiring Preconcentration or postirradiation Separations

E. Atuosplierie Particulates

1. Instrumental Analysis

2. Analysis of Elements Requiring Preconcentration or Postirradiation Separations

Acknowledgment

Bibliography

Appendix - Pertinent Nuclear Data Useful in Neutron Activation Analysis of Marine Environmental Samples 
NEUTRON ACTIVATION TECHNIQUES FOR THE MEASUREMENT OF TRACE METALS IN THE MARINE ENVIRONMENT

\author{
D. E. Robertson \\ Battelle \\ Pacific Northwest Laboratory \\ Richland, Washington 99352 \\ R. Carpenter \\ University of Washington \\ Seattle, Washington
}

I. INTRODUCTION

Anthropogenic wastes enter the marine environment from river drainage, from the atmosphere and from direct coastal discharges. Once these pollutants have entered the oceans they become entrained in complex biogeochemical and physical processes which serve to either disperse or reconcentrate the various contaminants. An essential feature of an effective marine environmental quality monitoring program is the capability for measuring these ocean pollutants at near-background levels in the main matrices involved in marine pollution--fresh waters, sea water, atmospheric particulates, biological organisms and sediments.

In monitoring the marine environment for metallic pollutants; few analytical methods offer the versatility and sensitivity achieved by neutron activation analysis (NAA). With the recent technological advances in developing high resolution solid state Ge(Li) detectors and their associated electronics, it is now possible to measure a wide spectrum of elemental constituents in virtually any environmental media by nondestructive, instrumental neutron activation analysis (INAA). Multielement analyses by this method is advantageous in two respects: (1) many of the potentially hazardous pollutant trace metals in various environmental matrices can be simultaneously measured and (2) many of the innocuous elements which greatly affect the biological availability and the biogeochemistry of the pollutant metals can likewise simultaneously be measured. When the concentrations of metallic pollutants are below the detection limits afforded by nondestructive INAA, either 
preconcentration or postirradiation separations of the elements of interest can be performed which, in most cases; increases the sensitivity for their measurement by orders of magnitude.

This treatise describes the technology and applications of NAA for the measurement of trace metal constituents in the marine environment. The contents are organized to indicate which trace elements can normally be measured by nondestructive INAA in the five matrices considered and, then when necessary, the chemistry required for preconcentrations and separations is provided. Emphasis has been placed on the measurement of the most potentially hazardous trace metals $\mathrm{Hg}, \mathrm{Cd}, \mathrm{Cu}, \mathrm{Ag}, \mathrm{As}$, $\mathrm{Sb}, \mathrm{Cr}, \mathrm{Se}$ and $\mathrm{Zn}$. Lead and $\mathrm{Sn}$ are not included since NAA is not a sensitive method for these elements.

\section{PRINCIPLES OF NEUTRON ACTIVATION ANALYSIS}

Neutron activation analysis is a nuclear method of elemental analysis in which the elements in a sample to be analyzed are made radioactive by irradiation with neutrons and the induced radioactive species are then identified and measured. The amount of a given neutron activation product that is formed during neutron irradiation is directly proportional to the amount of its parent isotope. Measurement of the radionuclide provides a measure of the total concentration of the parent element.

The basic equation for activation is

$$
W=\frac{A M}{\sigma f \phi\left(1-e^{-\lambda t}\right) \times 6.02 \times 10^{23}}
$$

where $W=$ weight of element irradiated, in grams

$$
\begin{aligned}
A= & \text { induced activity in disintegrations/sec at } \\
& \text { the end of irradiation } \\
\mathrm{f}= & \text { flux of neutrons used in the irradiation, } \\
& \text { in neutrons/cm } / \mathrm{sec} \\
\sigma= & \text { the activation cross section for the nuclear } \\
& \text { reaction concerned, in } \mathrm{cm}^{2}
\end{aligned}
$$


where $\phi=$ fractional abundance of the particular isotope of the element concerned

$M=$ atomic weight of that element

$\lambda=$ the decay constant of the induced radionuclide,

$t=$ irradiation time, in seconds

From the above equation it is obvious that the detection sensitivity for a given element by this method can be improved by increasing the neutron flux and/or the irradiation time. The relative detection sensitivities for all of the elements in the periodic table are a function of their activation cross section for the nuclear reaction concerned, the decay constant of the induced radionuclide, the atomic weight of that element and the fractional abundance of the particular isotope of the element concerned. For most elements, NAA is an extremely sensitive method of analysis, as evidenced in Tables 1, 2, 3, 4, 5, 6 and 7 . A notable exception is lead, an important ocean pollutant which is best measured by isotope dilution-mass spectrometry, or possibly atomic absorption spectrometry.

The concentration of an element in a sample can be calculated from the above equation using a flux monitor and if the radiation detector is calibrated for the neutron activation product of interest. However, the easiest and most accurate method for quantifying the concentration of any element is to include with the irradiation of the sample a standard of known weight of the element being determined. Then the weight of the element being determined is obtained as follows:

$\frac{\text { Weight of element in unknown }}{\text { Weight of element in standard }}=\frac{\text { Activity of element in unknown }}{\text { Activity of element in standard }}$ This method obviates the need for careful neutron flux monitoring and counting instrument calibrations, since the only measurements that are required are the relative counting rates of the neutron activation products of the element of interest in the unknown and in the standard. This comparative method requires that the sample and standards be both irradiated and counted under axactly the same conditions. 
The neutron activation method of analysis does not distinguish between various physicochemical forms of an element in a particular sample, but provides a measure of its "total" concentration. However, if different physicochemical specimens of the same element are separated prior to the neutron irradiation, NAA can provide a measure of each specific form.

In practice, the fundamental steps in a typical NAA are:

1) Irradiate weighed quantities of the sample and standard in suitable containers for a sufficient time to give adequate radioactivity for the element to be determined.

2) After the irradiation, INAA is accomplished by simply counting the samples and standards on $\mathrm{Ge}(\mathrm{L} i)$ and/or NaI(Tl) gamma-ray spectrometers at optimum times following the irradiation to directly measure elements producing short, intermediate and long-lived neutron activation products.

3) Compare the radioactivity of samples and standards under identical counting conditions, making decay corrections, Compton corrections and background corrections when necessary.

4) If INAA does not provide the desired sensitivity radiochemically separate the activation product(s) of interest from the interferring radionuclides and count the separates in the same geometries as the standards.

5) To insure that the gamma-ray being measured is due solely to the radionuclide of interest, check the half-life of the activity to be certain it is decaying at the proper rate.

For more detailed discussions of the basic theory, fundamentals and applications of NAA, the readers are referred to the following references: Anonymous (1971); Barbier (1969); DeVoe and LaFleur (1969); Guinn and Lukens (1965); Kruger (1971); Lenihan and Thompson (1969); Lutz, et al (1971) Rakevic (1970); Ryan (1973) and Smales (1967). 


\section{NEUTRON IRRADIATION FACILITIES AND PROCEDURES}

The most generally applicable neutron source for trace level activation analysis is the high flux nuclear reactor. Most of these reactors normally operate at power levels in the range of 10 to 1000 kilowatts and produce thermal neutron fluxes of $10^{11}$ to $10^{13} \mathrm{n} / \mathrm{cm}^{2} / \mathrm{sec}$. Reactors used in such work are generally of the research type and are becoming increasingly available for use by the scientific community. Neutron irradiations should preferably be performed in rotator tubes which accommodate specimen racks that rotate at about one revolution per minute to uniformly expose all of the samples to the axial horizontal neutron flux emanating from the fuel element core. In a typical irradiation, up to 48 samples and standards can be irradiated in one rotator tube simultaneously. Although the axial, horizontal neutron flux gradients in each rotator tube are minimized by rotating the samples, there exists a small vertical flux gradient which must be accounted for by placing a standard at each tier of samples if they are stacked vertically. "Rabbit" irradiations are used for activating samples for periods of seconds to minutes, where the induced activity of interest is a short-lived isotope, one having a half-life in the range of seconds to minutes. Samples are activated and counted one at a time (usually purely instrumentally), with the reactor operating steadily and a standard sample of the element of interest is similarly activated and counted at intervals.

\section{SAMPLE PREPARATION}

A. Materials and Manipulations

A tremendous advantage of using INAA is that sample handing and manipulations are reduced to a minimum, thereby greatly reducing the probability of contaminating a sample. Contamination problems are particularly severe when dealing with natural waters. The problems of contamination in trace element analysis have been thoroughly dealt with in the literature (Robertson, 1968; 1972; Thiers, 1957 a,b). 
Solid samples, such as sediments, biological tissue, air filters and sea and fresh water salts are normally weighed and heat sealed in cleaned polyethylene or polypropylene vials ranging in size from $1 \mathrm{cc}$ to $10 \mathrm{cc}$. Sample size can range from a few milligrams to tens of grams depending upon the sensitivity required and sample size available. Desiccation of sediments and biological tissue prior to encapsulation is accomplished by either freeze-drying or ovendrying at $105^{\circ} \mathrm{C}$. Special precautions are necessary when drying samples for trace $\mathrm{Hg}$ analyses to avoid losses by volatilization. These precautions are discussed in the section dealing with mercury analysis by NAA.

Natural waters, especially seawater, must usually be evaporated to dryness if the samples are to be irradiated for an extended period, since gaseous radiolysis products $\left(\mathrm{H}_{2}, \mathrm{O}_{2}\right.$ and other gases) are generated and produce high pressures which rupture the plastic irradiation vials. Desiccation is accomplished by either freeze drying or slowly evaporating the water under an infra-red heat lamp. Again, great care must be taken not to volatilize $\mathrm{Hg}$ and other volatile elements during these drying operations.

Water samples ran be neutron irradiated directly, without evaporation, if the water is sealed in quartz vials. However, in the case of seawater, the radiolysis products build up dangerously high pressures which have even shattered sealed quartz vials and this method is not recommended for routine use. In addition, quartz contains much higher levels of impurities than polyethylene or polypropylene and is a potential source of contamination. Tanner, et al (1972), and Brune and Landstrom (1966) have described a method for neutron irradiating 30 to $80 \mathrm{ml}$ samples of fresh water in a frozen state in polyethylene containers as a means of preserving the samples prior to and during the neutron irradiation. 
It is important that samples in a given set be encapsulated in reproducible, identical geometries so that all samples will be neutron irradiated in a known orientation. Elemental standards should be encapsulated and irradiated identically as the samples. Standards should be prepared in a matrix as close to the sample matrix as practically possible in order to minimize problems such as neutron self-shielding, irreproducible activation geometries and interferring nuclear reactions. For example, when neutron activating large quantities of sea salts, the elemental standards should be added to an equivalent amount of $\mathrm{NaCl}$ encapsuled in the same geometry as the sample. However, if sample sizes are kept very small, matrix matching is not a critical requirement for the types of samples normally encountered in the marine environment.

The use of standard reference materials of known elemental composition as activation standards is a converient method of simulating the sample matrix. A wide variety of reference materials are available for use as biological and geological standards. The National Bureau of Standards supplies orchard leaf, tuna meal and bovine liver as standard reference materials for analysis of biological material. The elemental concentrations in these materials are gradually being certified by the National Bureau of standards and may become useful activation standards in the future. The U. S. Geological survey supplies a wide variety of geological standard reference materials which have well documented elemental concentrations (Flanagan, 1969; Fleischer, 1965), and these are the best available reference materials for analysis of marine sediments and atmospheric particulates. The Environmental Protection Agency (EPA) has provided three freshwater sediments which many laboratories have analyzed for mercury. Two have mercury levels of $\sim 45$ and ح105 ppm Hg, respectively, which are much higher concentrations than normally found in natural sediments. The 
third has $00.06 \mathrm{ppm}$ and is at the lower end of most mercury values in sediments. These sediments are available from J. H. Finger, Environmental Protection Agency, Surveillance and Analyses Division, Athens, Georgia. Frequently, however, individual elemental standards must be prepared and included with the irradiations when the concentrations of those particular elements are not sufficiently high in the standard reference materials to be accurately measured.

To date, no standard reference natural water samples are available and analysts are required to prepare their own elemental standards. However, the EPA has made available six water reference samples which when diluted as prescribed will give different concentrations of $\mathrm{As}, \mathrm{Cd}, \mathrm{Cr}, \mathrm{Cu}, \mathrm{Pb}$, $\mathrm{Se}, \mathrm{Zn}$ and a few other metals in the ppb concentration range. These samples are available from J. A. Winter, Methods Performance Evaluation Activity, National Environmental Research Center, EPA, Cincinnati, Ohio (45268).

B. Preconcentration and Postirradiation Separations

In most cases the only matrices that require preconcentration of some trace elements prior to neutron activation are fresh and sea waters, where the natural elemental concentrations are near or below the parts per billion range, thus requiring large volumes of sample to achieve the desired sensitivity. Atmospheric particulates are naturally preconcentrated from large volumes of air during their collection on various filter media. Generally, the trace metal levels in marine organisms, sediments and atmospheric particulates are sufficiently high that convenient sized samples can be neutron activated and postirradiation radiochemical separations be performed. 
Postirradiation separations are usually the most desirable, because once the radioactive species are produced, any amounts or types of stable reagents and labware can be used in the chemical manipulations without contaminating the samples with the elements being measured. However, in the case of sea salts, if trace elements with shortlived ( $<1$ to 2 days) neutron activation products are to be measured, the trace elements must be separated from the NaCl matrix before neutron irradiation, since high radiation doses result from the large concentrations of ${ }^{24} \mathrm{Na}$ and ${ }^{38} \mathrm{Cl}$ which are produced when sea salts are neutron activated.

Preconcentration schemes for natural waters can be very simple, involving perhaps only the removal of much of the major activity component, such as ${ }^{24} \mathrm{Na}$. Alternatively, the separations can be made groupwise, and both such procedures are usually followed by gamma-ray spectrometry to obtain final specific measurement of each individual neutron activation product. Occasionally, and especially where the highest possible sensitivity is required, very thorough preconcentration or postirradiation separations are necessary. In the following sections chemical separation schemes are given for those elements of interest which cannot be measured in the various matrices by purely INAA.

\section{GAMMA-RAY SPECTROMETRY}

Since all of the elements of interest in this work, except $\mathrm{Pb}$ and $\mathrm{Sn}$, form neutron activation products with easily measurable gamma-rays, this section will be concerned only with gammaray spectrometry involving solid state Ge(Li) diode detectors and NaI(Tl) scintillation crystals.

The excellent resolution (about $3 \mathrm{KeV}$ ) provided by Ge (Li) diode detectors has revolutionized INAA. Heretofore, single NaI(TI) crystals were capable of resolving only a few of the major constituents in complex mixtures of radionuclides. 
Ge(Li) detectors, however, can resolve the gamma rays of nearly all neutron activation products formed in marine environmental matrices, if their concentrations are sufficiently high to be detected. A good example of this improved resolution is shown in Figure 7 (page 31), which compares the gamma-ray spectra of neutron activated sea salts counted on both a NaI(TI) crystal and a Ge(Li) diode detector. The main disadvantage of Ge(Li) detectors is their relatively low efficiency, compared to NaI(T1) crystals. However, for most neutron activated samples the lower efficiency of the Ge(Li) detectors is not a serious problem, since sufficiently high concentrations of the neutron activation products of the elements of interest can normally be produced in high flux nuclear reactors.

The basic principles and applications of Ge(Li) diode detectors. have been adequately described in the literature (Bertolini and Coche, 1968; Brown, et al, 1969 ; Camp, 1967; Cooper, 1973; Bearnaley and Northrop, 1966; Heath, R.L., 1969; Hollander, 1966; Keil and Bernt, 1972; Lutz, et al, 1971). Briefly, the hardware required for a basic Ge( $\mathrm{L} i$ ) gamma-ray spectrometer is the Ge(Li) detactor, a preamplifier, an amplifier, and a 2000 or 4000 channel pulse height analyzer.

While Ge(Li) detector systems of greater versatility and sophistication have been constructed (for example, cooper and Perkins, 1972) ordinary Ge(Li) detector systems are adequate for measuring a large group of neutron activation products in environmental samples.

In practice, the neutron activated samples and standards are transferred from the irradiation containers into standard counting geometries, which may consist of polyethylene vials of various sizes or some other suitable containers. Care must be taken to assure that the samples and the standards are encapsulated in identical counting geometries. Relatively small differences in orientation of the samples and standards within the containers can lead to serious errors if the containers 
are counted on or closc to the Ge(Li) detector. This is especially important for such unusually shaped samples such as filters and resins. One must not be seduced into placing the samples on the detector to increase counting efficiency without experimentally evaluating the geometry factors. The samples and standards are then positioned on or near the Ge(Li) detector in a fixed geometry and counted for a sufficient length of time to achieve the necessary counting statistics. Small differences in geometries in a set of samples can be minimized by counting the samples several $\mathrm{cm}$ away from the $\mathrm{Ge}(\mathrm{Li})$ detector if sufficient activity is present.

NaI(Tl) detector systems are most useful when sensitivity is the main concern, since NaI(Tl) detectors are approximately 10 to 100 times more efficient than Ge(Li) diode detectors. NaI(TI) crystals of various geometries are commercially available but the most commonly employed are well crystals or solid, cylindrical crystals of various sizes normally ranging from about 3 to 13 inches in diameter and about 3 to 9 inches thick. The background and Compton response of these crystals can be substantially lowered by anticoincidence shielding with large plastic phosphors or annular NaI(Tl) crystals (Perkins and Robertson, 1965; Wogman, et al, 1967, for examples). Two large anticoincidence-shielded NaI(T1) detectors can be designed to count as dual coincidence gamma-ray spectrometers, thereby greatly increasing the sensitivity and selectivity of NaI(TI) gamma-ray spectrometry (Perkins and Robertson, 1965).

These large crystal NaI(Tl) systems are particularly. applicable for measuring traces of neutron activation products which have been radiochemically separated from an interferring matrix. Their high efficiencies permit very low levels of radioactivity to be measured in relatively short counting intervals. 
DITA HANDLING

Interpretation of gamma-ray spectra obtained from NaI(TI) and $\mathrm{Ge}(\mathrm{Li})$ detectors typically involves location of peaks in the spectra, determination of peak energies, measurement of peak areas and calculation of concentrations of the elements from which the gamma-ray emitters were formed. In NaI(Tl) spectrometry, if the radionuclide mixture is quite simple, the peak areas can be obtained by manual subtraction of background and compton contributions. However, if the radionuclide mixture contains more than 3 or 4 gamma emitting radionuclides, the spectrum stripping is most conveniently and accurately accomplished by using a computer program designed for that purpose. Because peak areas in $\mathrm{Ge}(\mathrm{Li})$ diode spectra are normally well resolved, determination of peak intensities by manual subtraction of the background and compton contribution can be readily accomplished in even very complex mixtures of radionuclides. Normally, an equal number of channels on each side of the peak area are selected to represent the contribution due to background and compton interferences and this contribution is manually subtracted from the peak area. However, if many routine analyses are required, the manual method can become tedious and time consuming and the most rapid and economical way to process the data is with a computer.

The development and application of computer programs for the analysis of gamma-ray spectra is, by no means, an elementary task. For computer analysis to be workable, spectrometer systems must be very electronically stable, precisely adjusted before counting and the spectra must be converted to a computer compatible form. Incorrect input of data often confuses a computer, resulting in termination of the analysis or computation of wrong answers. Once these problems have been overcome, a computer analysis of the gamma-ray spectra is capable of rapidly converting the spectra directly into concentrations of individual consituents. However, unless one is tooling up for the analysis of a large number of routine samples, it is often more trouble 
than it is worth to develop a computer program designed to quantify INAA. It is a good practice to occasionally check computer programs by hand calculations to ensure that they are operating as designed.

For more detailed discussions of the use of computers for data reduction the readers are referred to the following material: DeVoe and Lafleur, 1969; Salmon and Creevy, 1970; O'Kelley, 1962.

\section{ELEMENTAL ANALYSES}

A. Fresh waters

1. Instrumental Neutron Activation Analysis Nearly all of the potential pollutant elements of interest can be measured in fresh waters (rain water, river water, lake water, tap water, etc) by INAA utilizing a very simple radiochemical group separation to remove interferring neutron activation products. Figure 1 illustrates the relative abundances of the major and some of the minor radionuclides formed during neutron activation of river water and their change in concentration with time. It is obvious that the high activity due to ${ }^{24} \mathrm{Na}$ will mask the gamma-ray spectra of all of the trace neutron activation products of the elements of interest, except ${ }^{38} \mathrm{Cl},{ }^{42} \mathrm{~K},{ }^{56} \mathrm{Mn}$ and possibly $8 \mathrm{~cm}$ Sr. Therefore, to measure the short-lived neutron activation products of $\mathrm{As}, \mathrm{Hg}, \mathrm{Cu}, \mathrm{Zn}, \mathrm{Ba}$ and $\mathrm{La}$, as well as several other elements of geochemical interest, it is necessary to remove the interferring ${ }^{24} \mathrm{Na}$.

Tanner, et al (1972), have described a simple two-step separation scheme which eventually permits the semiinstrumental measurement of about 19 trace elements (see Figure 2). The method simply consists of passing a neutron activated water sample, containing $0.1 \mathrm{mg}$ carriers of $\mathrm{Na}, \mathrm{K}, \mathrm{kb}$ and $\mathrm{Cs}$, through a column of Dowex $1 \times 2$ anion exchange resin which has been converted 


\section{FIGURE 1}

RELATIVE CONCENTRATIONS OF INDUCED RADIONUCLIDES IN RIVER WATER FOLLOWING AN INTEGRAI THERMAL NEUTRON IRRADIATION OF $2 \times 10^{16} \mathrm{n} / \mathrm{cm}^{2}$. EMPHASIZING THE PROBLEM OF MEASURING SHORT-IIVED ACTIVATION PRODUCTS BY INAA IN THE PRESENCE OF HIGH CONCENTRATIONS OF SODIUM-24

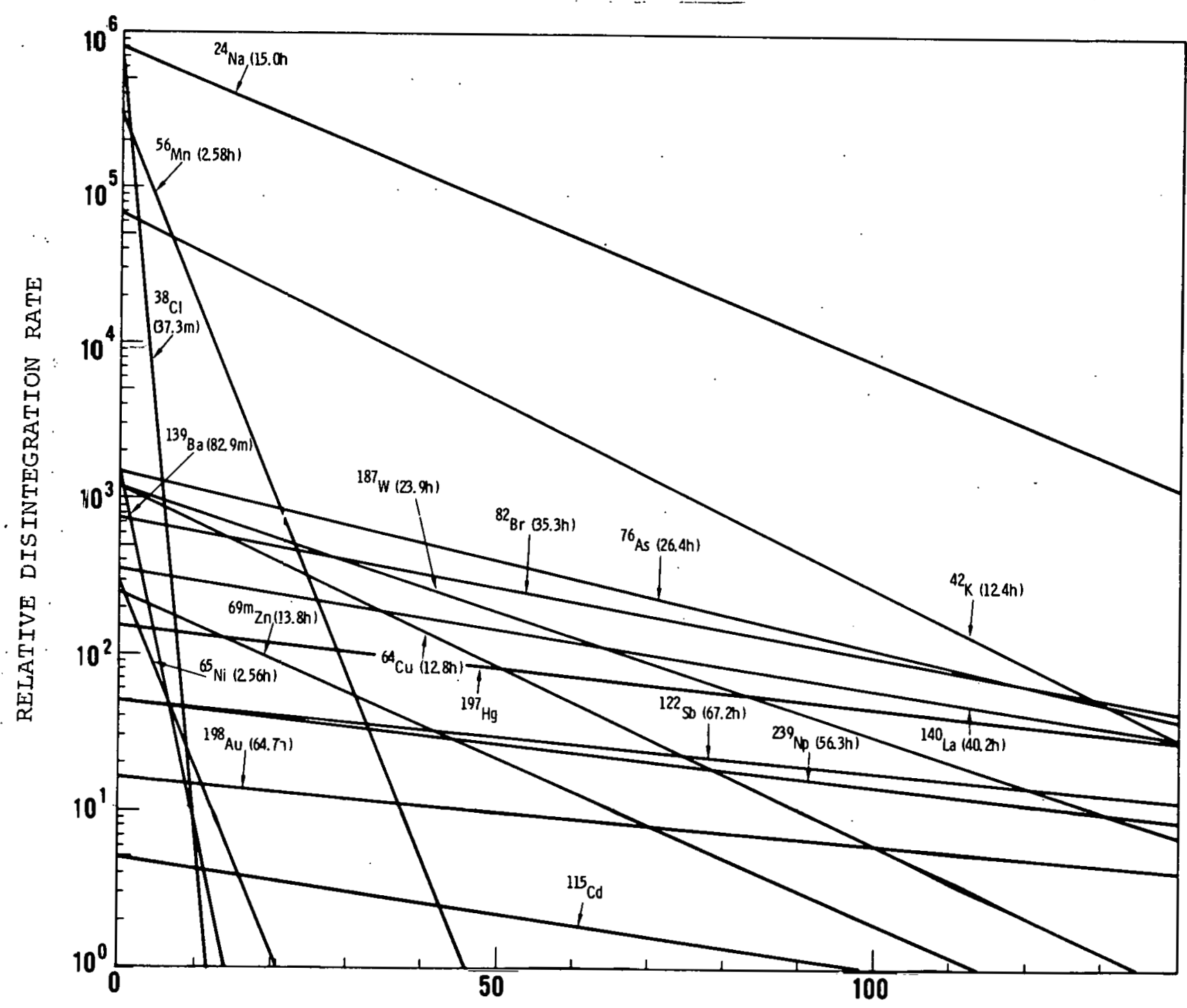

TIME AFTER NEUTRON IRRADIATION (HOURS) 
F IGURE 2

MULTIELEMENT ANALYSIS OF TRACE CONSTITUTENTS IN NATURAL WATER

BY, NEUTRON ACTIVATION. TWO-GROUP CHEMICAL SEPARATIONS AND GAMMA-RAY ANALYSIS

(after Tanner, et al, 1972)

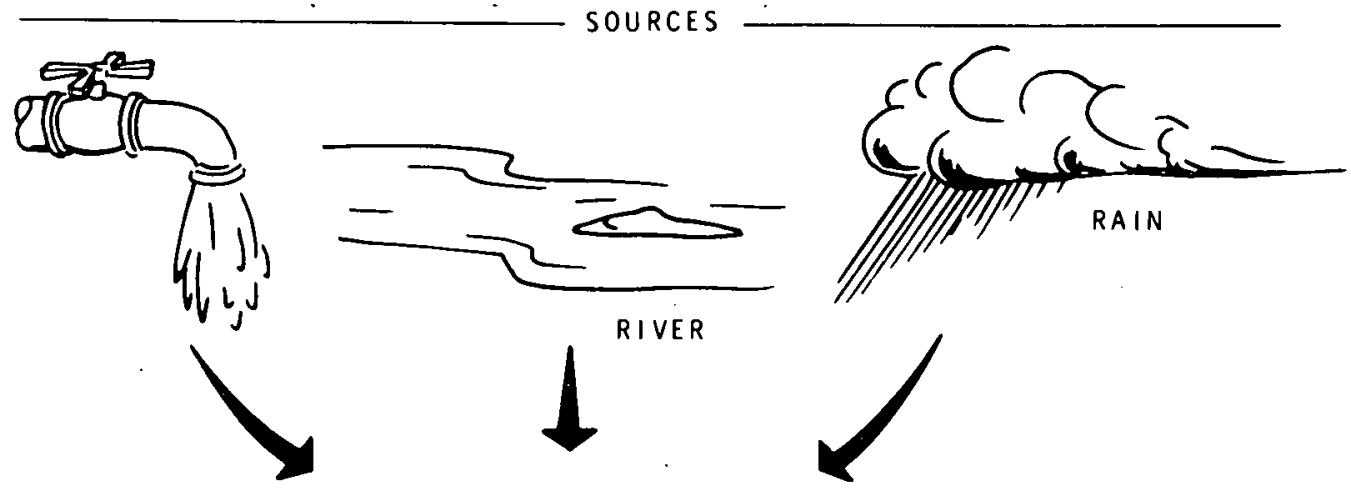

WATER SAMPLE QUICK FROZEN AT COLLECTION SITE TO PREVENT CONTAMINATION OR ADSORPTION ON CONTAINER WALLS

SAMPLE ETCHED

TO REMOVE SURFACE CONTAMINATION, MELTED AND FILTERED
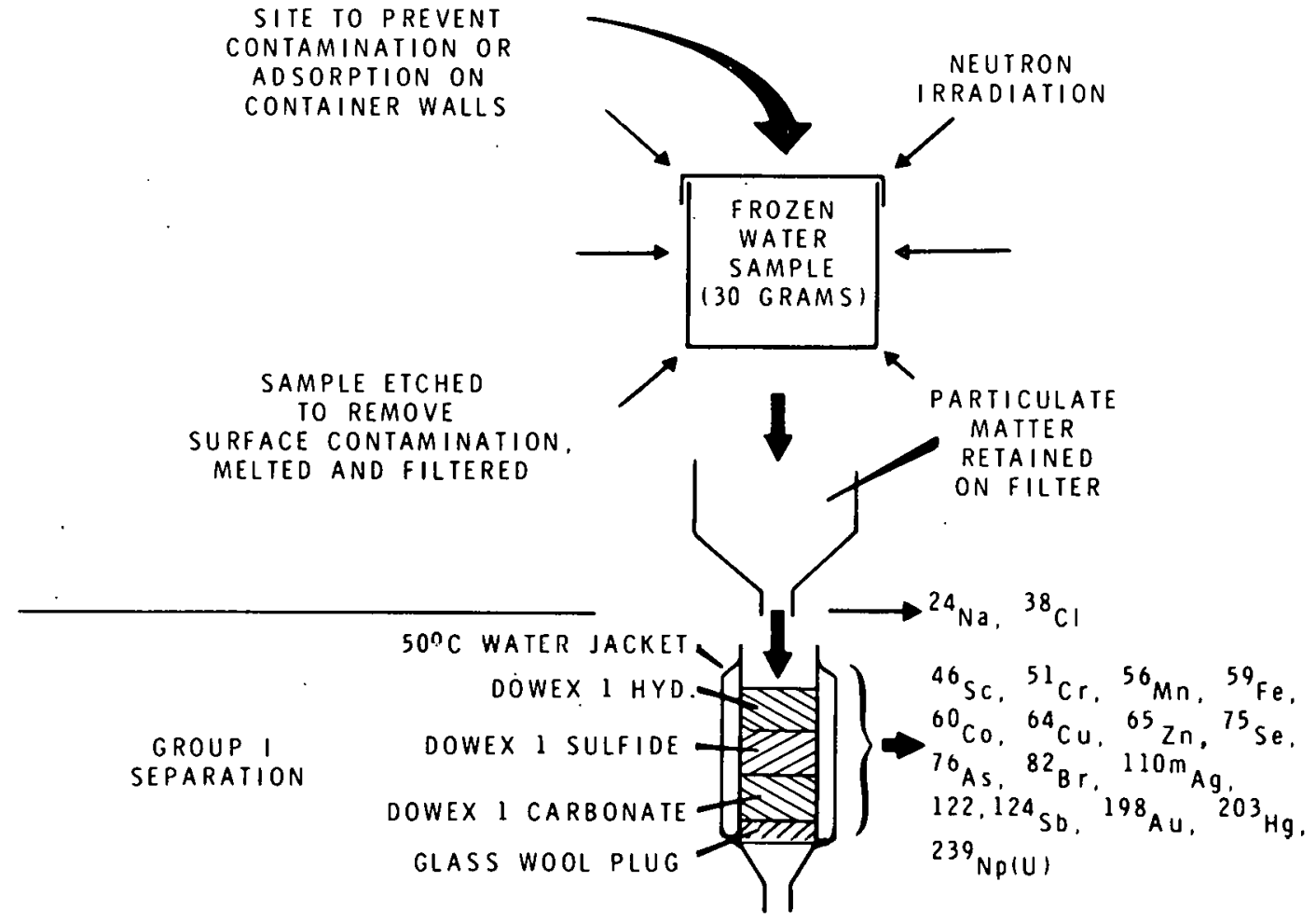

GROUP II SEPARATION

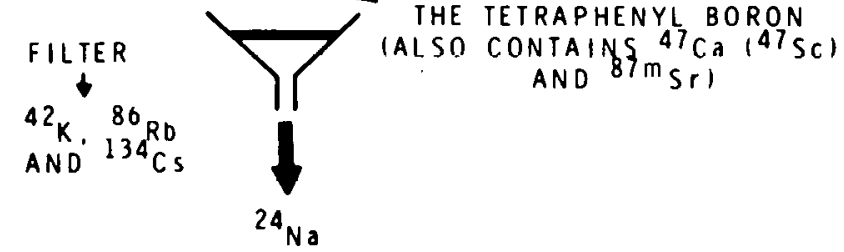

EFFLUENT CONTAINING ALKALI METALS PRECIPITATE K, RD, CS, AS IHE TETRAPHENYL BORON (ALSO CONTAINY $47 \mathrm{CA} 147 \mathrm{SC}$ ) 
to $\mathrm{OH}^{-}, \mathrm{s}^{=}$and $\mathrm{CO}_{3}^{=}$forms by contacting with $1 \mathrm{M}$ solutions of $\mathrm{NaOH}, \mathrm{Na}_{2} \mathrm{~S}$ and $\mathrm{Na}_{2} \mathrm{CO}_{3}$, respectively. All trace activation products, except the alkali metals and the alkaline earths, are retained on the resins by a precipitation-ion exchange mechanism. The resin is then rinsed with distilled water, transferred into plastic counting containers and counted directly on a $\mathrm{Ge}(\mathrm{Li})$ detector. The column effluent, containing the radionuclides ${ }^{24} \mathrm{Na},{ }^{42} \mathrm{~K},{ }^{86} \mathrm{Rb},{ }^{134} \mathrm{Cs}$ and traces of neutron activation products of the alkaline earths $\mathrm{Ca}, \mathrm{Ba}$ and $\mathrm{Sr}$, is treated with an excess of $4 \%$ sodium tetraphenylboron to precipitate $\mathrm{Cs}, \mathrm{K}$ and $\mathrm{Rb}$ and the precipitate is washed, filtered and counted directly on a $\mathrm{Ge}(\mathrm{Li})$ detector. Standard solutions of the elements of interest are sealed in quartz vials, irradiated, transferred to plastic counting containers and counted in the same geometries as the samples to quantify the measurements by the comparator method. Figure 3 illustrates the gamma-ray spectra of the short-lived radionuclides measured in neutron activated river water before and after the separation scheme. Figure 4 illustrates the gamma-ray spectra of the long-lived neutron activation products contained on the resins and tetraphenylboron precipitate by counting 23 and 24 days after the irradiation. Eleven additional neutron activation products can be detected from these counts.

In Table 1 the elements which can normally be measured in fresh waters by this semi-INAA technique are indicated, together with the detection limits of many of the elements of interest. Without any separations at all it would still be possible to measure $\mathrm{Ag}, \mathrm{Br}, \mathrm{Cl}$, $\mathrm{Co}, \mathrm{Cr}, \mathrm{Cs}, \mathrm{Fe}, \mathrm{Mn}, \mathrm{Na}, \mathrm{Rb}, \mathrm{Sb}, \mathrm{Sc}, \mathrm{Se}, \mathrm{U}, \mathrm{Zn}, \mathrm{Ag}$ and occasionally $\mathrm{Hg}$, simply by counting the neutron activated river water samples at several optimum times 
GAMMA-RAY SPECTRUM OF NEUTRON ACTIVATED RIVER WATER

(after Tanner, et al, 1972)

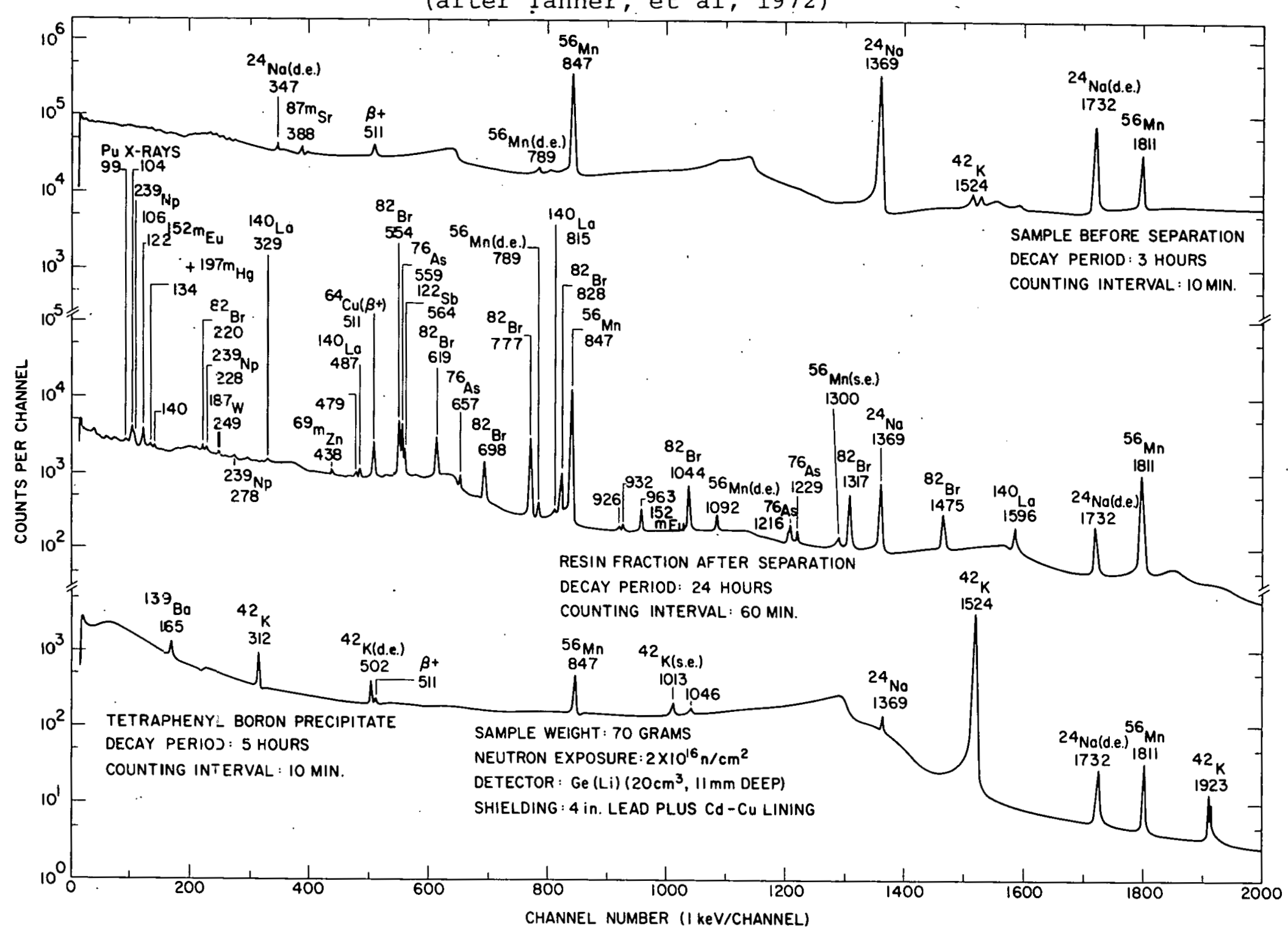




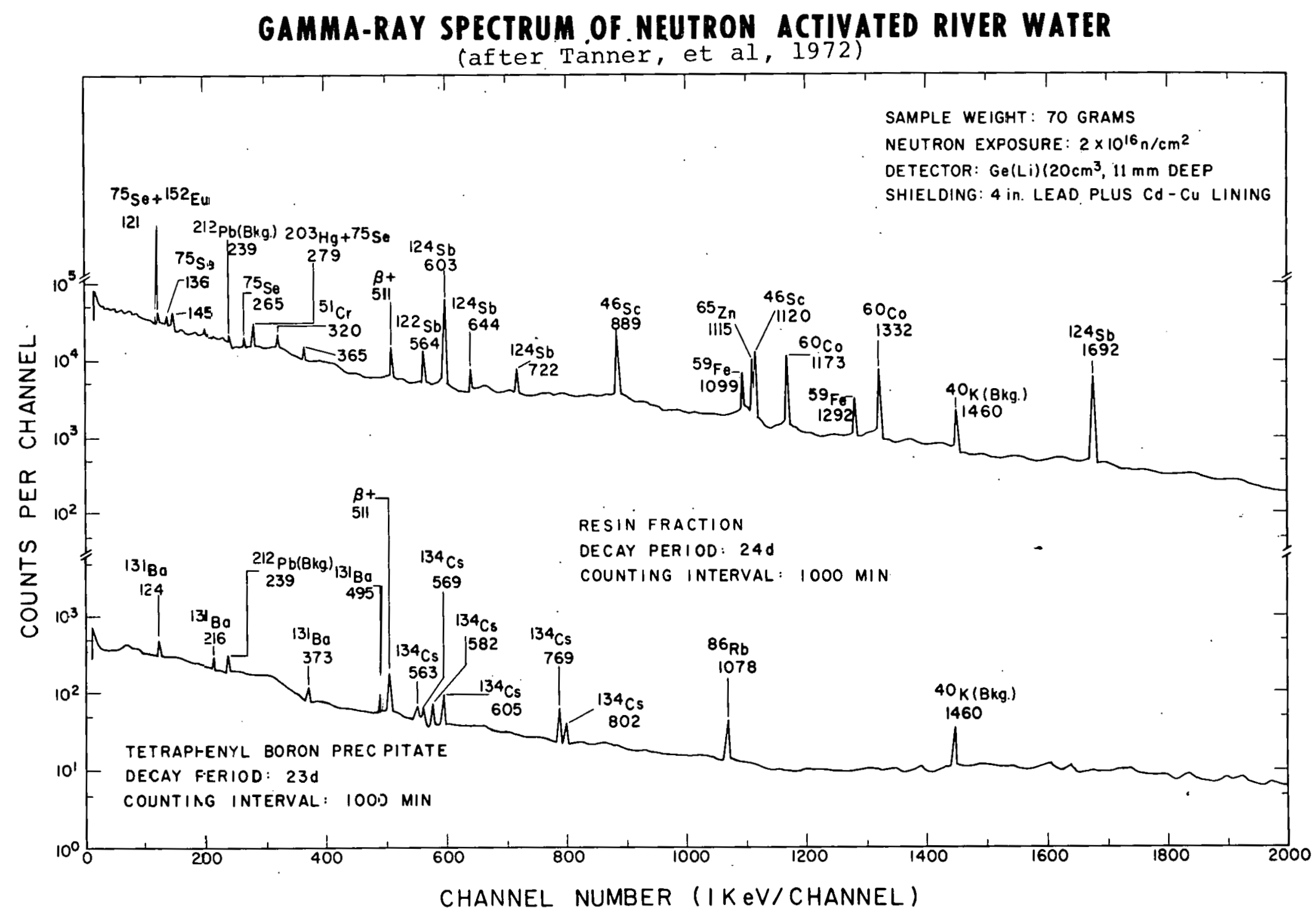


TA.BT,F. 1

APPROXIMATE LIMITS OF DETECTION OF VARIOUS TRACE METALS IN RIVER WATER BY NEUTRON ACTIVATION AND GROUP SEPARATIONS

\begin{tabular}{|c|c|c|c|}
\hline Element & $\begin{array}{l}\text { Approx. Estimate of } \\
\text { Conc. in River Waters } \\
(\mu \mathrm{g} / 1)(\mathrm{a}) \\
\end{array}$ & $\begin{array}{l}\text { Detection Limits by NAA } \\
\text { After Group Separation } \\
(\mu \mathrm{g} / 1)(\mathrm{b})\end{array}$ & $\begin{array}{l}\text { Allowable } \\
\text { Limits (c) } \\
(\mu \mathrm{g} / 1) \text { (c) }\end{array}$ \\
\hline Ag* & 0.3 & 0.01 & 50 \\
\hline As & 2 & 0.1 & 50 \\
\hline $\mathrm{Ba}$ & 10 & 5 & 1000 \\
\hline $\mathrm{Br} *$ & 20 & 0.01 & \\
\hline $\mathrm{Cd}$ & -- & 50 & 10 \\
\hline $\mathrm{Cl}$ * & 7800 & 100 & \\
\hline $\mathrm{Co} *$ & 0.2 & 0.01 & \\
\hline $\mathrm{Cr} *$ & 1 & 0.1 & $50\left(\mathrm{Cr}^{+6}\right)$ \\
\hline $\mathrm{Cs}$ * & 0.02 & 0.01 & \\
\hline $\mathrm{Cu}$ & 7 & 0.1 & 1000 \\
\hline $\mathrm{Fe}^{*}$ & -- & 10 & 300 \\
\hline $\mathrm{Hg}$ & 0.07 & 0.1 & $(10)$ \\
\hline $\mathrm{K}^{*}$ & 2300 & 10 & \\
\hline$M n *$ & 7 & 0.01 & 50 \\
\hline $\mathrm{Na*}$ & 6300 & 10 & \\
\hline $\mathrm{Rb}$ * & 1 & 0.1 & \\
\hline $\mathrm{Sb}$ * & 0.3 & 0.01 & \\
\hline $\mathrm{SC}^{\star}$ & 0.004 & 0.001 & \\
\hline $\mathrm{Se}^{*}$ & 0.2 & 0.1 & 10 \\
\hline $\mathrm{Zn}$ * & 20 & 1 & 5000 \\
\hline
\end{tabular}

* Elements normally detected and measured by INAA

(a) after Turekian (1969)

(b) after method of Tanner, et al (1972)

Thirty to eighty $\mathrm{ml}$ water samples; integrated thermal neutron exposure $2 \times 10^{16} \mathrm{n} / \mathrm{cm}^{2}$; count for $10 \mathrm{~min}, 60 \mathrm{~min}$, and $1000 \mathrm{~min}$. after decay times of 3 hrs, 24 hrs and 23 days, respectively; $20 \mathrm{Cc} \mathrm{Ge}(\mathrm{Li})$ detector.

(c) U. S. Public Health Service (1962). 
following the irradiation (approximatcly 4 hours, 3 days and 20 days). The radiochemical separations permit the measurement of $\mathrm{As}, \mathrm{Cu}, \mathrm{La}$ and $\mathrm{K}$.

Table 1 also lists the approximate limits of detection for 2.0 elements in river water utilizing the method of Tanner, et al (1972), and compares these limits with maximum allowable concentrations of some of the more toxic heavy metals in drinking water, as established by the U. S. Public Health Service. As indicated in Table 1, this semi-INAA technique can be used to detect most heavy metal pollutants in fresh waters at concentrations well below maximum permissible limits. Of the most toxic heavy metals, only $\mathrm{Cd}, \mathrm{Pb}, \mathrm{Sn}$ and occasionally $\mathrm{Hg}$ cannot be measured by this method.

Edgington and Lucas (1970) and Girardi and Sabbioni (1968) have developed a method of removing ${ }^{24} \mathrm{Na}$, the major interference in NAA of environmental samples, based on selective retention of the ${ }^{24} \mathrm{Na}$ on hydrated antimony pentoxide (HAP). All neutron activation products, except ${ }^{24} \mathrm{Na}, \quad{ }^{82} \mathrm{Ta}$ and $233 \mathrm{~Pa}$, reportedly pass through the $\mathrm{HAP}$ column and are measured by Ge(Li) gamma-ray spectrometry. The method of Edgington and Lucas (1970) provides a breakdown into further group separations by selective elution of the effluent from the HAP separation from Dowex $1 \times 8$ anion exchange resin.

Neutron activation analysis is not a sensitive method for $\mathrm{Pb}$ and $\mathrm{Sn}$, but $\mathrm{Cd}$ can be measured by preconcentration from 500-1000 $\mathrm{ml}$ of fresh water. Since $\mathrm{Hg}$ and $\mathrm{Ag}$ are normally present in uncontaminated fresh waters at concentrations near or below their detection limits for INAA, preconcentration or postirradiation separations are described below for these elements, as well as for $\mathrm{cd}$. 
Suspended Particulate Matter

Particulate matter suspended in natural waters carry significant percentages of the total amounts of several elements in the waters. To determine the partitioning of the elements between the two phases, it is desirable to isolate the suspended particulate material, by either centrifugation or membrane filtration. The preferred method is by membrane filtration, and the usual filter pore size used is about 0.3 to $0.5 \mu$. Both Millipore and Nuclepore filters have commonly been used for this purpose, and both filters contain comparable traces of impurities. It is recommended that as large a water sample as practically possible be filtered to obtain enough suspended matter for elemental analysis and to reduce the probability of contamination during the filtering process.

Several types of all-plastic filtering devices are commercially available (Millipore Corporation; General Electric Co., for examples) which are ideal for filtering natural waters. The usual procedure for INAA of suspended particulates is to collect the material on tared filters (Millipore? Nuclepore, etc.), desiccate to a sonstant wejght and reweigh the filters to obtain a gravimetric analysis. Nuclepore $B$ filters offer the most desirable taring characteristics because they absorb less moisture than other types of membrane filters. Weighing of membrane filters on an analytical balance may present some problems due to the electrostatic charge which accumulates on the filters. This can be overcome by inserting a special $\alpha$-emitting Po source (Watson Brothers, Northern California Division, Scientific Instruments, San Mateo, California) inside the balance case. The ionization of the air produced by the a particles neutralizes the electrostatic charge on the membrane filter. 
The weighed filters are then encapsuled in plastic irradiation vials and neutron activated, together with appropriate standards of the elements of interest. After the irradiation, the samples are then counted on a $\mathrm{Ge}(\mathrm{Li})$ detector at optimum decay times to measure up to 24 trace elements. Since the suspended particulate matter in natural waters is usually a combination of both geological and biological material, the discussion of which elements can be measured and the detection sensitivities which can be achieved will be covered in the following sections concerned with analyses of biological and geological material.

2. Analysis of Elements Requiring Preconcentration or Postirradiation Separations

The trace metals of pollution concern which frequently need to be preconcentrated or separated from natural waters to achieve the necessary sensitivity for NAA are $\mathrm{Hg}, \mathrm{Cd}, \mathrm{Ag}, \mathrm{As}$ and Se. Procedures are given below which accomplish these separations.

Mercury Procedure I

Under certain conditions, mercury losses by diffusion through polyethylene irradiation containers during neutron activation of fresh waters have been reported (Bate, 1971). Individual investigators should evaluate their particular methods of encapsulating and irradiating natural waters to insure that such losses are not significant. One method of minimizing such losses is to irradiate the water sample in a frozen state, as indicated in the following procedure.

Landstrom and Wenner (1965) have reported a simple procedure for the isolation of $203 \mathrm{Hg}$ from neutron activated natural water samples. A $30 \mathrm{ml}$ water sample, neutron irradiated in a frozen state for 12 hours at a flux of about $2 \times 10^{12} \mathrm{n} / \mathrm{cm}^{2} / \mathrm{sec}$, is transferred to a distillation flask, acidified with $\mathrm{H}_{2} \mathrm{SO}_{4}$, and $\mathrm{H}_{2} \mathrm{O}_{2}$ and $\mathrm{HBr}$ are added and the $\mathrm{Hg}$ is distilled as the bromide.

The distillate is made $3.5 \mathrm{M}$ in $\mathrm{H}_{2} \mathrm{SO}_{4}$ and $0.1 \mathrm{M}$ in $\mathrm{HCl}$, $\mathrm{H}_{2} \mathrm{O}_{2}$ is added, $\mathrm{Br}$ is driven off and the solution is passed through a small column of Dowex $2 \times 10$ anion exchange resin in the sulfate form. The column, containing the sorbed 
$\mathrm{Hg}$, is rinsed with $0.1 \mathrm{~N} \mathrm{HCl}$ to elute $\mathrm{Sb}, \mathrm{As}$ and $\mathrm{Se}$ and the anion resin is then counted to determine $197-203 \mathrm{Hg}$ activity. Mercury standards, irradiated with the samples, are counted in the same geometry to quantify the measurements. Recovery is reported to be $96 \%$.

Mercury Procedure II

Ljunggren, et al (1970), have reported a method for separating radiomercury from neutron activated fresh waters. Water samples 0.3 to $10 \mathrm{ml}$ in volume are sealed in cleaned quartz vials and irradiated for 2 to 3 days in a thermal neutron flux of about $3-4 \times 10^{12} \mathrm{n} / \mathrm{cm}^{2} / \mathrm{sec}$. After a short cooling period, the samples and $20 \mathrm{mg}$ of Hg carrier are digested in a Bethge apparatus with $15 \mathrm{ml}$ of 10:1 mixture of concentrated nitric acid and sulfuric acid. To the digested solution is added a mixture of $5 \mathrm{ml}$ of $70 \%$ perchloric acid and $0.5 \mathrm{gm}$ of glycine in $5 \mathrm{ml}$ of water. The $\mathrm{Hg}$ is distilled from the solution until the temperature reaches $250^{\circ} \mathrm{C}$. The distillate (containing the $\mathrm{Hg}$ ) is diluted to about $300 \mathrm{ml}$ with distilled water and $\mathrm{Hg}$ is electrodeposited on a tared thin gold foil. A platinum foil $(2 \times 3 \mathrm{~cm})$ is used as an anode and a thin gold foil ( 1 × $3 \mathrm{~cm}$ ) as the cathode, and these electrodes are immersed in the electrolyte about $6 \mathrm{~cm}$ apart. About $95 \%$ of the $\mathrm{Hg}$ is electrodeposited after 15 hours of electrolysis at a voltage of 4 to 6 volts and a current of 0.3 to 0.5 ampere. When the electrolysis is completed, the electrolyte is neutralized with $\mathrm{NH}_{4} \mathrm{OH}$, using phenol red as an indicator. Before the current is interrupted, the gold foil is rinsed with distilled water and alcohol, then air dried and reweighed to obtain the chemical yield. The foil is sealed in a plastic bag and the $197-203 \mathrm{Hg}$ activity measured by gamma-ray spectrometry. The use of a sample of $10 \mathrm{ml}$ places the detection limit at $0.01 \mathrm{ng} / \mathrm{ml}$.

\section{Mercury Procedure III}

Brune and Jirlow (1967) have developed a method for separating radiomercury from neutron activated fresh water samples based on the isotopic exchange technique. reported by Kim and Silverman (1965). Water samples are neutron irradiated in polyethylene containers In a frozen state for 3 to 13 hours at a flux of about $2 \times 10^{12} \mathrm{n} / \mathrm{cm}^{2} / \mathrm{sec}$. After the irradiation, the water samples are transferred to a distilling flask equipped with a reflux condenser. A 3:1 mixture of nitric and sulfuric acid is added and the sample refluxed for about 20-40 minutes. The solution is cooled and then diluted with an equal volume of water and neutralized to a $\mathrm{pH}$ of 1 to 2 by addition of $\mathrm{NH}_{4} \mathrm{OH}$. The solution 
is transferred to an appropriate sized bottle and $0.5 \mathrm{gm}$ of $\mathrm{NH}_{4} \mathrm{Br}$ is added, followed by $0.2 \mathrm{ml}$ of elemental inactive $\mathrm{Hg}$. The solution is vigorously stirred for 40 minutes to allow the radiomercury to exchange with the inactive $\mathrm{Hg}$. The $\mathrm{Hg}$ is then separated on a sintered glass filter disk, washed with water and acetone, and then dissolved in $5 \mathrm{ml}$ of concentrated nitric acid. The nitric acid is transferred to an appropriate container and $197-203 \mathrm{Hg}$ is measured by gamma-ray spectrometry.

\section{Mercury Procedure IV}

Thatcher and Johnson (1970) have developed a precipitation method for measuring $\mathrm{Hg}$ in fresh waters by NAA. water samples are collected in $20 \mathrm{ml}$ quartz vials which are immediately sealed. The vial is neutron irradiated for 4 hours in a flux of $5 \times 10^{12} \mathrm{n} / \mathrm{cm}^{2} / \mathrm{sec}$. One day after the irradiation the vial is opened, carrier $\mathrm{Hg}$ in nitric acid is added and the sample is allowed to stand one hour to desorb $\mathrm{Hg}$ from the quartz. The sample is transferred to a polyethylene centrifuge tube and ammonium persulfate is added to oxidize organo-mercurials. Sodium bisulfite is added to reduce excess persulfate and to dilute ${ }^{2{ }^{4} \mathrm{Na} \text { and }}$ ${ }^{3} \mathrm{~S}$ activities. Stannous chloride is next added to precipitate metallic mercury the precipitate is centrifuged and counted for $19{ }^{7} \mathrm{Hg}$. Sensitivity is $0.05 \mu \mathrm{g} / 1$ but could be improved by simply activating the samples for a longer period of time.

The above four methods are capable of measuring only "total" mercury (inorganic plus organic forms), since the postirradiation digestion procedures should destroy any organically bound $\mathrm{Hg}$. Although these four procedures have been developed especially for neutron activation analysis of $\mathrm{Hy}$ in fresh watcrs, therc are numerous postirradiation radiochemical separation schemes developed for other matrices which can be slightly modified to meet the needs of fresh water analyses. These procedures are contained in an excellent monogram by Roesmer (1970).

If $\mathrm{Hg}$ concentrations in fresh waters are too low to measure in 1 to $30 \mathrm{ml}$ volumes as described in the above procedures, preconcentration from large volumes ( 0.2 to 2 liters) of water is necessary. Lai and Weiss (1962) have described a very simple preconcentration procedure, which has subsequently been used at Battelle-Northwest Laboratory (Robertson, unpublished work, 1972) for preconcentration of Hg from seawater and should be applicable to fresh waters. A water sample (0.2 to 2 liters) is adjusted to a $\mathrm{pH}$ of 3 to 4, warmed to about $60^{\circ} \mathrm{C}$ and $20 \mathrm{ml}$ of a $1 \%$ solution of 
thionalid in acetone is added. The water samples are then chilled in a refrigerator and the thionalid crystals (containing quantitatively cocrystallized $\mathrm{Hg}$ ) are collected on membrane filters, washed with high purity water, and encapsulated in polyethylene vials for neutron activation analysis. $20{ }^{3} \mathrm{Hg}$ can be directly measured in the neutron activated thionalid by Ge(Li) gamma-ray spectrometry several weeks after the irradiation.

Weiss and Crozier (1972) have described a method of preconcentrating $\mathrm{Hg}$ from seawater, which should be equally applicable to fresh waters. Mercury is separated from $500 \mathrm{ml}$ of water by adding $1 \mathrm{mg}$ of $\mathrm{Cu}$ carrier and coprecipitating the $\mathrm{Hg}$ with the $\mathrm{Cu}$ as sulfides by bubbling $\mathrm{H}_{2} \mathrm{~S}$ gas into the water for 30 seconds. The CuS precipitate is collected by membrane filtration, washed with high purity water and encapsulated in a polyethylene vial for neutron activation. After the irradiation the $197-203 \mathrm{Hg}$ is radiochemically separated and measured by gamma-ray spectrometry.

Minczewski (1967), Mizuike (1965) and Joyner (1967) have described a number of group preconcentration procedures which should be adaptable for separating $\mathrm{Hg}$ from large volumes of water.

Cadmium Procedures

Landstrom and Wenner (1965) have outlined a postirradiation radiochemical separation scheme for the measurement of $\mathrm{Cd}$ by neutron activation analysis, based on its anion exchange properties. However, the method is not generally applicable, because it lacks the sensitivity to measure environmental levels of $\mathrm{cd}$ in only 10 to $30 \mathrm{ml}$ of Eresh waters. Therefore, it is necessary to preconcentrate the $c d$ from large volumes ( 0.2 to 2 liters) of water prior to the neutron activation step. Riley and Taylor (1963) and Goya and Lai (1967) have described a preconcentration method for Cd in seawater, based on adsorption onto Chelex-100 chelating resin, and this method should be adaptable to fresh waters. Other preconcentration schemes, as outlined by Minczewski (1967) and Mizuike (1965) should be rather easily adaptable for preconcentrating cd from large volumes of fresh waters.

After the preconcentrates have been neutron activated, appropriate radiochemical separations as outlined by Devoe (1960) may be used to further isolate the radiocadmium. 


\section{Silver Procedures}

Kharkar, et al (1968), have measured Ag in river waters by NAA. Their procedure is to irradiate freeze-dried river salts, having added $25 \mathrm{mg}$ of spec-pure $\mathrm{Na}_{2} \mathrm{CO}_{3}$ per $100 \mathrm{ml}$ of river water to provide enough salts with which to conveniently work. Several weeks after the irradiation the salts are dissolved in $20 \mathrm{ml}$ of $1 \underline{\mathrm{N}} \mathrm{HCl}$ and carriers added. Silver chloride is filtered off, rinsed with $0.1 \mathrm{~N} \mathrm{HCl}$, dissolved in a small volume of $\mathrm{HNO}_{3}$ and then converted to an $\mathrm{NH}_{4} \mathrm{OH}$ solution. The solution is scavenged with $\mathrm{Fe}(\mathrm{OH})_{3}$ to remove interferences and the $\mathrm{Ag}$ is then precipitated with $\mathrm{H}_{2} \mathrm{~S}$. The precipitate is dissolved in concentrated $\mathrm{HNO}_{3}$, diluted with water and the $\mathrm{Ag}$ is reprecipitated in dilute $\mathrm{HCl}$. The AgCl precipitate is washed, dried and counted for $110 \mathrm{~m}_{\mathrm{Ag}}$.

The same thionalid preconcentration procedure (Lai and Weiss, 1962) described earlier for $\mathrm{Hg}$ can be used to isolate Ag from large volumes of fresh waters, to achieve the desired sensitivity needed for its measurement. Silver can then be directly measured by counting the neutron activated thionalid crystals (containing quantitatively cocrystallized $\mathrm{Ag}$ ) on a $\mathrm{Ge}(\mathrm{Li})$ diode detector or dual coincidence gamma-ray spectrometer. If further radiochemical purity is required, the method of Kharkar, et al (1968), can be used.

\section{Arsenic Procedures}

Arsenic can usually be measured in river or lake waters by the semi-INAA method of Tanner, et al (1972). However, in some natural waters, particularly precipitation, the As must be preconcentrated from large volumes of water. The As procedures described in the following section for seawater analyses are completely applicable for the determination of As in fresh waters.

\section{Selenium Procedure I}

As in the case of As, for some natural waters the Se must be preconcentrated to achieve the necessary sensitivity. Kharkar, et al (1968) have developed a separation scheme for measuring $S e$ in fresh waters. One hundred $\mathrm{ml}$ of freeze-dried river salts (containing $25 \mathrm{mg}$ of spec-pure $\mathrm{Na}_{2} \mathrm{CO}_{3} / 100 \mathrm{ml}$ of river water as a salt carrier) is neutron activated. Several weeks after the irradiation the sample is dissolved in $1 \mathrm{~N} \mathrm{HCl}$, carriers are added, AgCl is filtered off and the solution is made $6 \underline{\mathrm{N}}$ in $\mathrm{HCl}$ and $\mathrm{H}_{2} \mathrm{~S}$ added to precipitate Mo and $\mathrm{Se}$ sulfides. 'The Mo sulfides are dissolved away in dilute 
$\mathrm{HNO}_{3}$ and the se sulfide is purified by dissolving in concentrated $\mathrm{HNO}_{3}$, precipitating Se with $\mathrm{SO}_{2}$, distilling off $\mathrm{Se}$ as the bromide and finally reducing $\mathrm{Se}$ as the metal with $\mathrm{NaHSO}_{3}$. The Se metal is filtered, washed, dried and counted to measure ${ }^{75}$ se activity.

Selenium Procedure II

Weiss, et al (1971), have measured se in melted samples of the Greenland ice sheet by NAA. One to 4 liter samples are acidified with $\mathrm{HNO}_{3}$ and evaporated to $1 \mathrm{ml}$ and neutron activated. After the irradiation the se is radiochemically separated by repeated precipitations of the Se metal carrier. The final se precipitate is filtered and beta-counted in a gas-flow proportional counter periodically to measure ${ }^{81} \mathrm{Se}$ and check its half-life. Yield is checked by counting carrier-free ${ }^{75} \mathrm{Se}$ added at the start of the procedure. Selenium concentrations as low as $5 \mathrm{ng} / \mathrm{kg}$ were measured.

\section{Chromium Procedures}

Chromium is frequently below the detection limit of INAA and must be preconcentrated from large volumes of fresh waters. The methods given for $\mathrm{Cr}$ measurements in the following section on seawater analysis are directly applicable for fresh waters.

\section{Suspended Particulate Matter}

The pollutant elements of concern contained on separated suspended particulate matter can be analyzed by postirradiation radiochemical separations once the material has been properly digested. Refluxing in $\mathrm{HNO}_{3}-\mathrm{H}_{2} \mathrm{SO}_{4}$ is normally a sufficient digestion procedure if siliceous materials are not present. If large amounts of silica are present, HF must be added to the acid digest to volatilize the silica. Care must be exercised to insure that volatile elements such as $\mathrm{Hg}$ are not lost during the digestion procedure.

\section{B. Sea Water}

1. Instrumental Analysis

Because of the tremendous amounts of ${ }^{24} \mathrm{Na}(15.4 \mathrm{hrs})$ which are produced during neutron irradiation of sea water, INAA of sea water is applicable only for those elements in sea water which have relatively long halflife activation products. From Figure 5, it is obvious 


\section{FIGURE 5}

RELATIVE CONCENTRATIONS OF INDUCED RADIONUCLIDES IN SEA WATER FOLLOWING AN INTEGRATED THERMAL NEUTRON EXPOSURE OF $5 \times 10^{-16}$ $\mathrm{n} / \mathrm{cm}^{2}$. EMPHASIZING THE PROBLEM OF MEASURING SHORT-LIVED ACTIVATION PRODUCTS IN THE PRESENCE OF HIGH CONCENTRATIONS OF SODIUM-24, BROMINE-82, POTASSIUM-42 AND SULFUR-35.

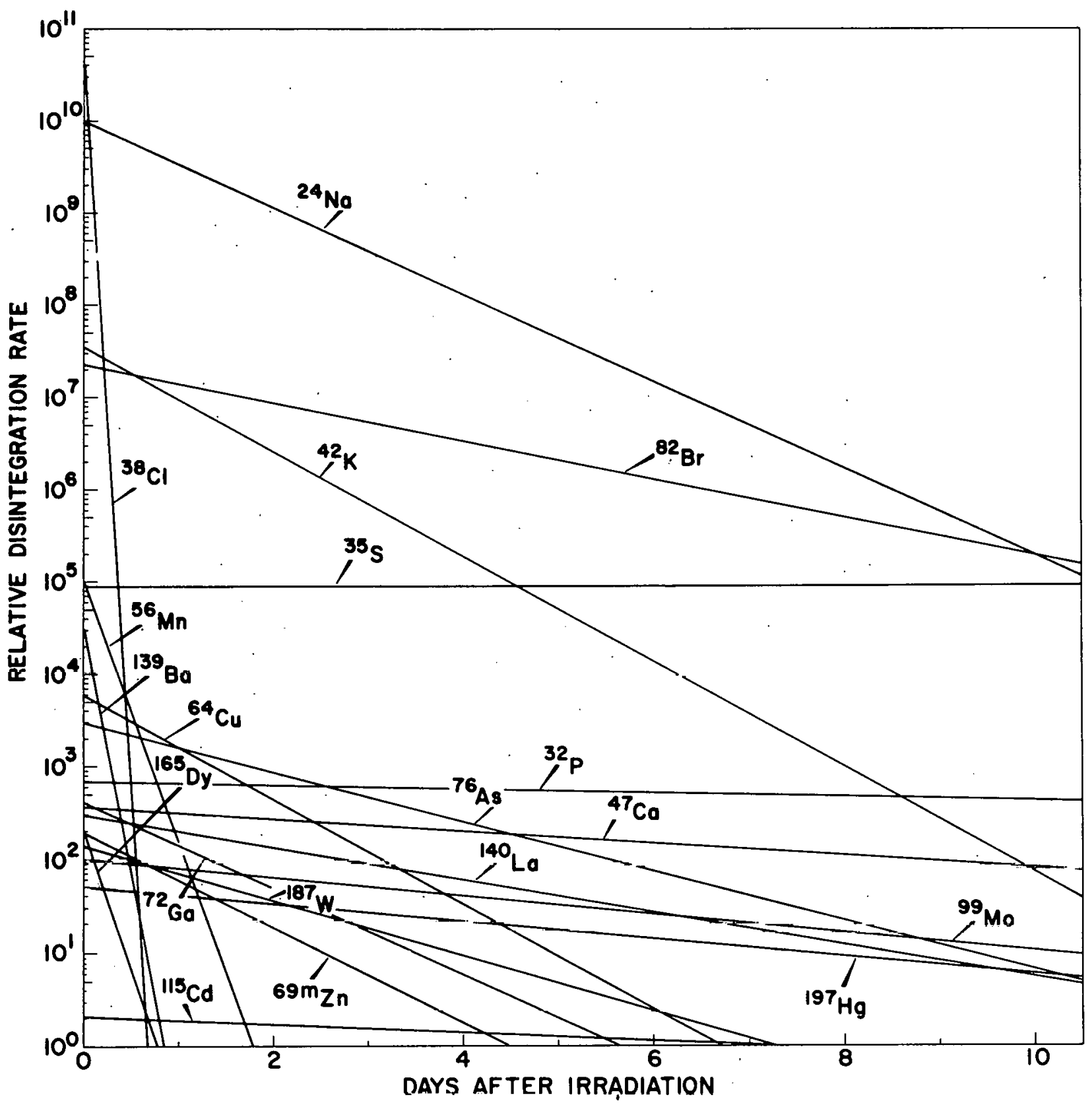


that none of the short-lived neutron activation products of interest could possibly be measured instrumentally, since the ${ }^{24} \mathrm{Na},{ }^{38} \mathrm{Cl},{ }^{42} \mathrm{~K}$ and ${ }^{82} \mathrm{Br}$ are orders of magnitude more abundant, and completely mask the gamma-ray contributions of the activation products of interest. For the INAA of sea.salts, the neutron irradiated samples are stored for about one month to allow these relatively short-lived interferring radionuclides to decay to tolerable concentrations.

Figure 6 shows that after about 24 days out of the reactor, the ${ }^{24} \mathrm{Na}$ has decayed to insignificant concentrations and ${ }^{82} \mathrm{Br}(36 \mathrm{hrs})$ is now the major gammaemitting interferring radionuclide. Bromine-82 decays with the emission of a large number of high energy gamma-rays which interfer with the measurement of the trace activation products of interest, and it is necessary to store the samples for another two weeks to allow the ${ }^{82} \mathrm{Br}$ to decay to tolerable levels. High concentrations of ${ }^{35} \mathrm{~S}$ and ${ }^{32} \mathrm{P}$ remain in the samples, but they are pure beta emitters and can be tolerated in the gamma-ray spectra.

The month-old activated sea salts are then transferred into a constant counting geometry (small polyethylene vials or stainless steel planchets) and counted directly on a Ge( $\mathrm{Li}$ ) diode detector or a dual coincidence gammaray spectrometer (Robertson, et al, 1968). The activated sea salt samples are encased in a thin (0.7 mm thick) lead container to attenuate the low energy bremsstrahlung radiation from the beta-emitters ${ }^{35} \mathrm{~S}$ and ${ }^{32} \mathrm{P}$. Figure 7 illustrates a typical gamma-ray spectrum of neutron activated sea salts counted on a $\mathrm{Ge}(\mathrm{Li})$ detector 54 days after the neutron irradiation, and demonstrates the tremendous resolution advantages of $\mathrm{Ge}(\mathrm{Li})$ detectors compared to NaI(TI) crystals. It is apparent that the eight trace eleneints, $S r, R b, C s, U, 3 b, Z n$, Te and Co, 
RELATIVE CONCENTRATIONS OF INDUCED RADIONUCLIDES IN SEA WATER FOLLOWING AN INTEGRATED THERMAL NEUTRON EXPOSURE OF $10^{18} \mathrm{n} / \mathrm{cm}^{2}$. EMPHASIZING THE PROBLEM OF MEASURING INTERMEDIATE-AND LONG-LIVED ACTIVATION PRODUCTS IN THE PRESENCE OF HIGH CONCENTRATIONS OF SODIUM-24, BROMINE-82 AND SULFUR-35.

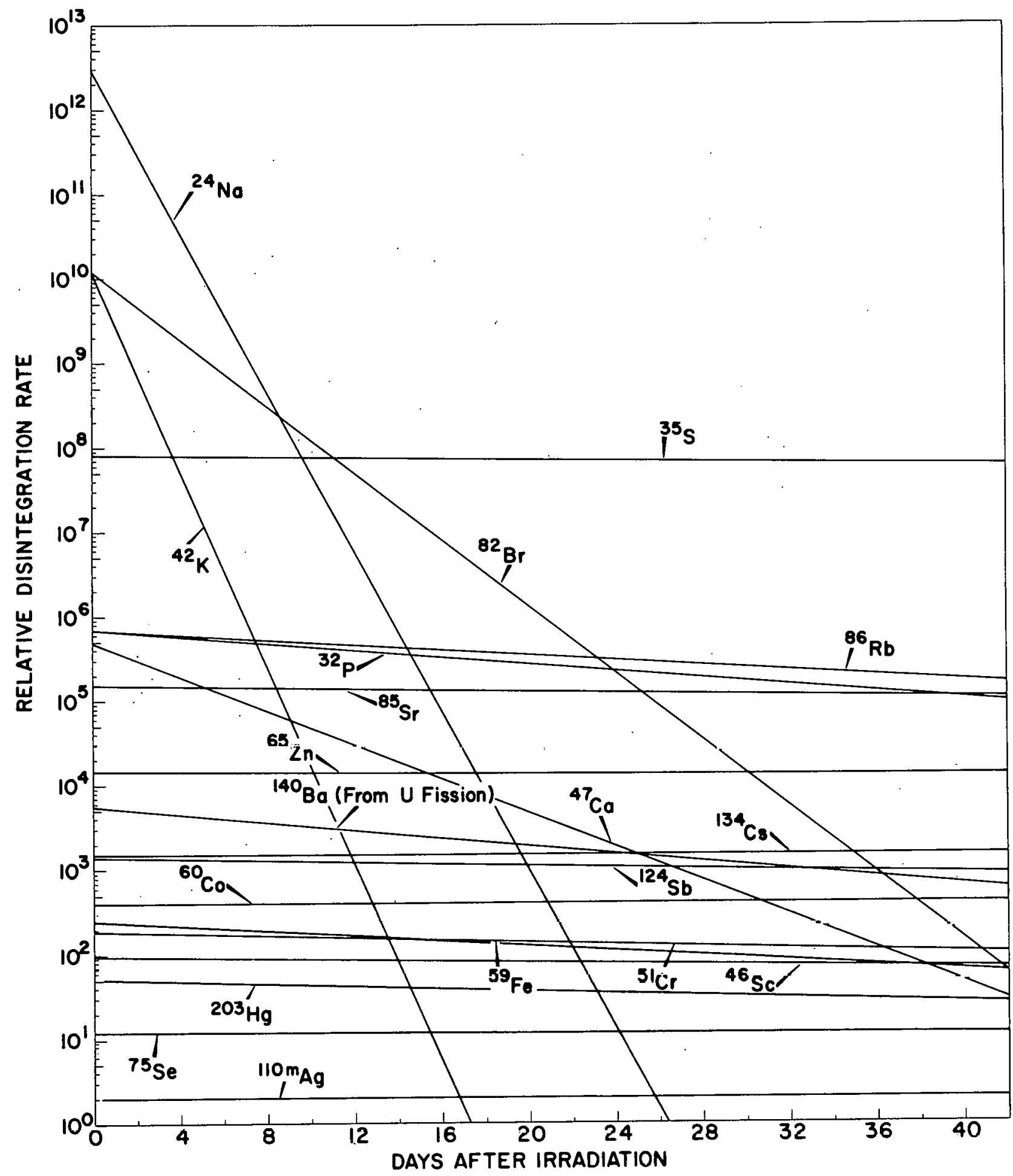


GAMMA-RAY SPECTRUM OF NEUTRON ACTIVATEO SEA WATER

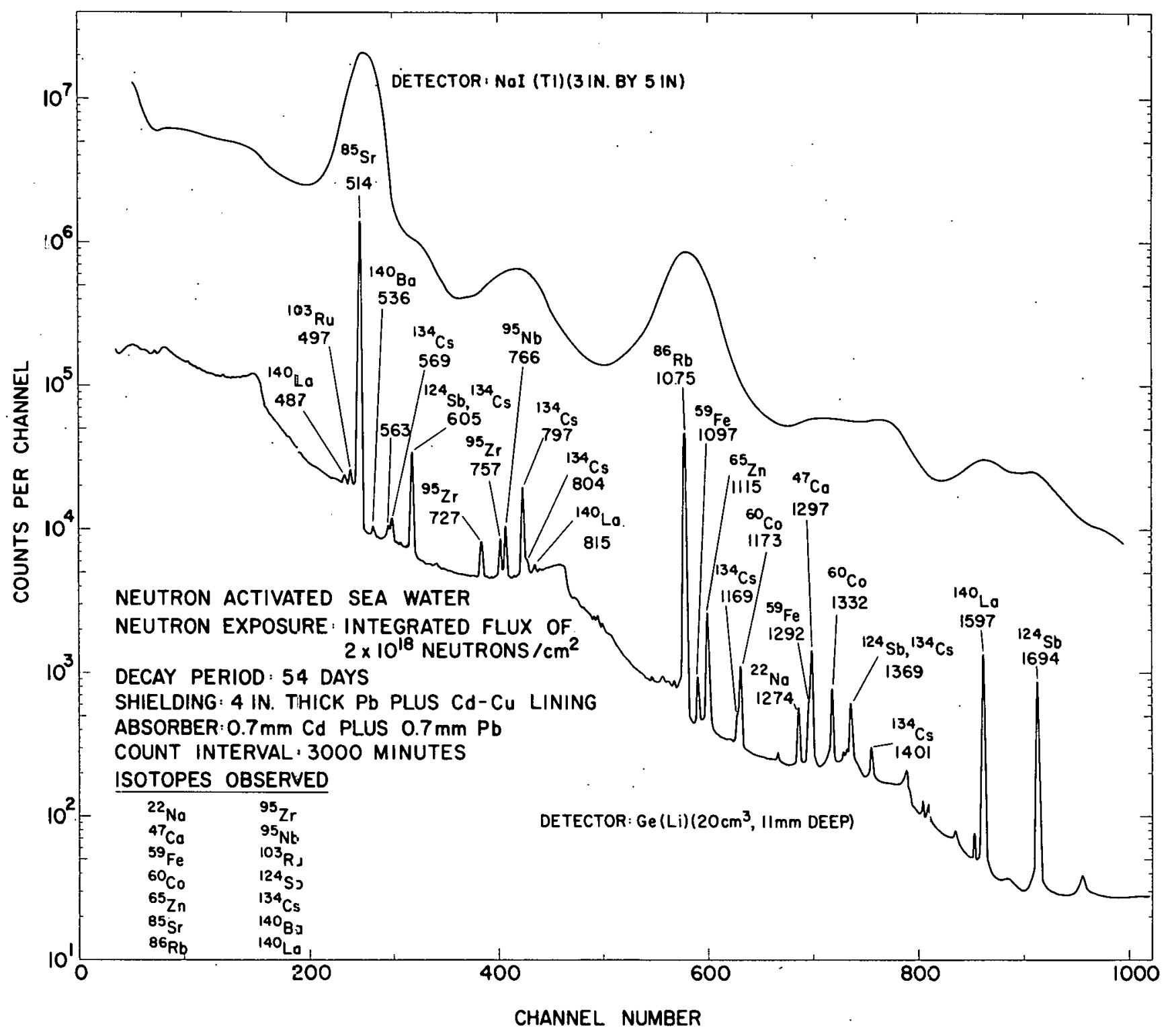




\section{TABLE 2}

\section{ESTIMATED DETECTION LIMITS FOR INSTRUMENTAL NEUTRON ACTIVATION ANALYSIS OF SEAWATER*}

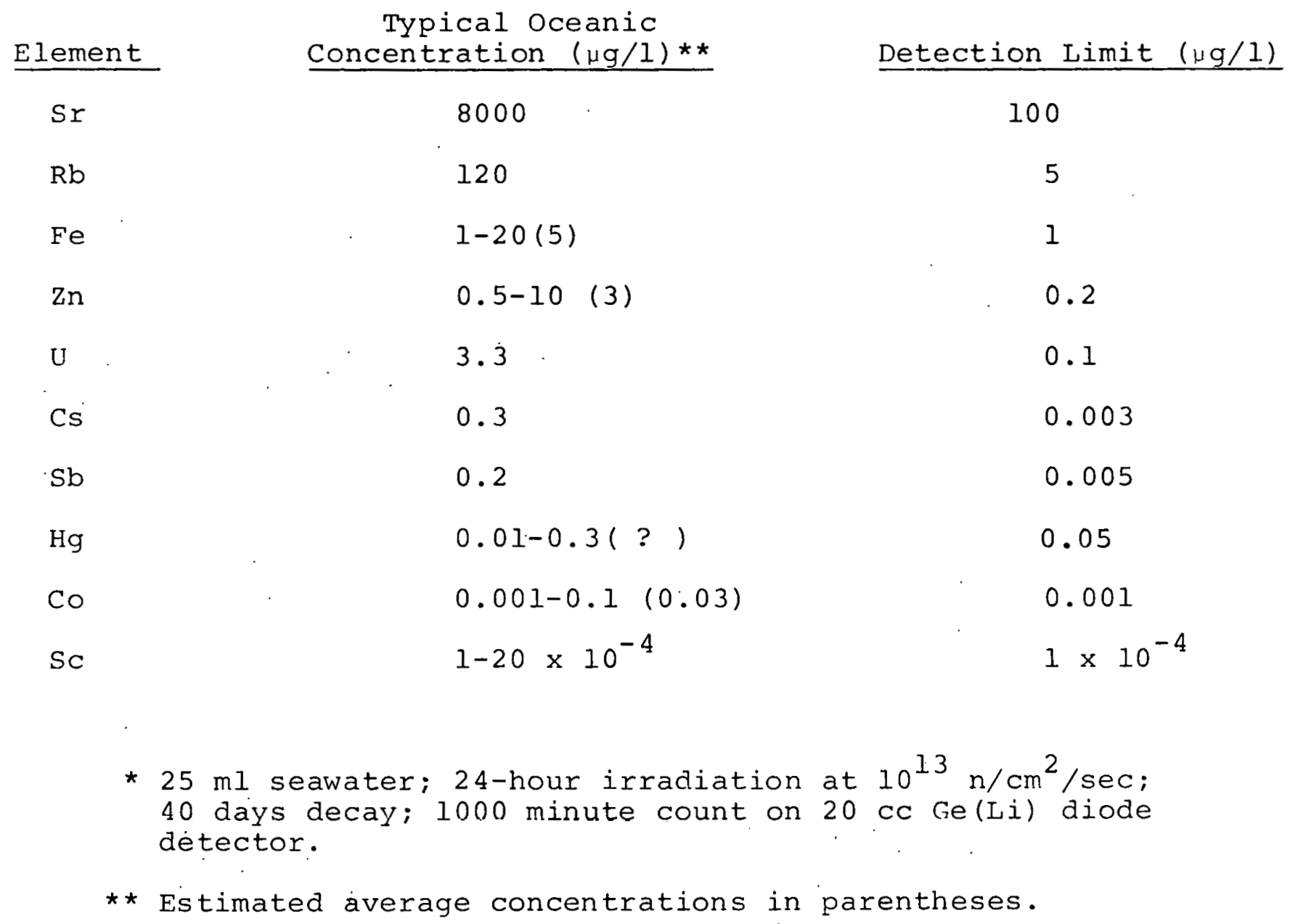


can be measured in sea salts by this technique. Only $\mathrm{Sb}$ and $\mathrm{Zn}$ are of immediate interest from an environmental pollution concern.

Table 2 lists the trace elements in sea water which can normally be measured by INAA and compares the detection limits of this method with the actual oceanic concentrations of the elements observed in sea water. It is obvious that this method is sufficiently sensitive to measure any of the naturally existing concentrations of these elements observed in the oceans. Mercury can be measured instrumentally in neutron activated sea salts by Ge(Li) diode spectrometry if the samples are irradiated in an extremely thermalized neutron flux. If the neutron flux contains an appreciable fast neutron component, large amounts of the pure beta-emitter ${ }^{32} \mathrm{p}$ are produced by a ${ }^{35} \mathrm{Cl}(\mathrm{n}, \alpha){ }^{32} \mathrm{P}$ reaction. The bremsstrahlung activity from the ${ }^{32} \mathrm{P}$ (maximum beta particle energy $1709 \mathrm{KeV}$ ) interfers with the sensitive detection of the $279 \mathrm{KeV}$ gamma ray from the $203 \mathrm{Hg}$ neutron activation product. The Hanford plutonium production reactors, which have now all been closed down, were among the few nuclear reactors in the U.S. which possessed the necessary highly thermalizcd neutron fluxes. The Triga type of research nuclear reactors, now commonly available throughout the country, do not possess the required neutron flux characteristics necessary for the INAA of mercury in sea salts.

It is often desirable to remove suspended particulate matter from sea water for trace metal analyses, especially in coastal or estuarine waters containing relatively high concentrations of biological, geological and detrital material. The t.rohniques for removal and analysis are essentially the same as those described earlier in the section dealing with fresh waters. 
ESTIMATED MINIMUM DETECTABLE CONCENTRATIONS OF POLLUTANT ELEMENTS IN SEAWATER BY INAA AND BY NAA WITH SEPARATIONS

\section{Trace \\ Elerrent}

$\mathrm{Hg}$

$\mathrm{Cd}$

$\mathrm{Ag}$

$A \subseteq$

$\mathrm{Cu}$

$\mathrm{Cr}$

$\mathrm{Zn}$

$\mathrm{Sn}$

$\mathrm{Se}$

Sk.
Typical Reported Concentrations in Open Ocean (Micrograms/Liter)

$$
\begin{aligned}
& 0.02-0.2 \\
& 0.06-0.7 \\
& 0.002-0.05 \\
& 2-3 \\
& 0.5-2 \\
& 0.02-0.6 \\
& 0.5-10 \\
& 0.02 \\
& 0.08 \\
& 0.2
\end{aligned}
$$

* $25 \mathrm{ml}$ seawater; 24 hour irrediation at $10^{1.3} \mathrm{n} / \mathrm{cm}^{2} / \mathrm{sec} ; 40$ days decay; 1000 minute count on $20 \mathrm{cC}$ Ge(Li) liode detector; based on $3 \alpha$ above Bkg-Compton contribution in peak areas.

* $500 \mathrm{ml}$ seawater; elements chemically separated; 24 hour irradiation at $10^{13} \mathrm{n} / \mathrm{cm}^{2} / \mathrm{sec}^{2}$ 3 days decay; 500 minute count on a $20 \mathrm{CC}$ Ge(Li) diode detector; based on twice Bkg contribution in peak areas.
Minimum Detectable Concentrations (in micrograms/liter)

\begin{tabular}{ll}
\hline INAA* & (in micrograms/liter \\
\hline 0.05 & 0.001 \\
16.000 & 0.001 \\
1.0 & 0.003 \\
Not Possible with Separations** & 0.0001 \\
Not Possible & 0.002 \\
0.3 & 0.003 \\
0.2 & 0.01 \\
Not Possible & 9 \\
0.2 & 0.02 \\
0.02 & 0.00003
\end{tabular}


Of the pollutant elements of interest only $\mathrm{Zn}$ and $\mathrm{Sb}$ can be measured in seawater by INAA. However, if preconcentration or postirradiation separations are performed, neutron activation can be used to measure all of the pollutant elements of interest, except $\mathrm{Pb}$ and $\mathrm{Sn}$. Table 3 lists the estimated minimum detectable concentrations of the potential pollutant trace metals of interest in seawater as measured by both INAA and NAA with separations from interfering radionuclides. These detection sensitivities are compared with the actual observed or estimated naturally occurring concentration ranges for these elements in the ocean. It is obvious that neutron activation with separations possesses the necessary sensitivity to measure all of these trace metals at naturally occurring concentrations well.above their detection limits. Some of the necessary preconcentration and/or postirradiation chemical separation schemes permitting the measurement of these elements in seawater are given below.

2. Analyses of Elements Requiring Preconcentration or Postirradiation Separations

Mercury Procedure I

It should be pointed out that nearly quantitative losses of $\mathrm{Hg}$ from unacidified seawater onto polyethylene storage containers is a serious sampling problem. Both $\mathrm{Hg}^{+}$and methyl Hg chloride are lost from solution by adsorption onto container walls. The $\mathrm{Hg}^{+}$and methyl $\mathrm{Hg}$ chloride can be kept completely in solution for long storage periods by acidifying the seawater to a pH of about 1.5 with high purity HCl (Robertson, unpublished results, 1972, Battelle-Northwest).

The method of Ljunggren, et al (1970), described previously for analyses of $\mathrm{Hg}$ in fresh waters (see Mercury Procedure II in the section on fresh waters) has been utilized to measure $\mathrm{Hg}$ in seawater. The procedure is identical to that for fresh waters, except that the neutron irradiated seawater samples must be stored in appropriate shielding until the very intense gamma-radiation resulting from high concentrations of ${ }^{24} \mathrm{Na}$ have decayed to workable levels. 
However, this procedure is not recommended, since the seawater irradiated in sealed quartz ampoules builds up tremendous pressures from radiolysis products and the quartz ampoules are dangerous to handle.

\section{Mercury Procedure II}

Weiss and Crozier (1972) developed a preconcentration and post irradiation separation for measuring $\mathrm{Hg}$ in seawater by neutron activation analysis. To $500 \mathrm{ml}$ of filtered, acidified ( $10 \mathrm{ml}$ conc. HCl per liter of seawater) seawater is added $\mathrm{I} \mathrm{mg}$ of $\mathrm{Cu}$ (II) carrier and the $\mathrm{Cu}$ is precipitated as the sulfide by bubbling $\mathrm{H}_{2} \mathrm{~S}$ gas into the seawater for 30 seconds. The $\mathrm{Hg}$ in the seawater is coprecipitated with the cus. The precipitate is collected on a membrane filter, rinsed with high purity water and placed in a $15 \mathrm{ml}$ polyethylene irradiation vial. The walls of the precipitation vessel were washed successively with 5,3 and $2 \mathrm{ml}$ volumes of nitric acid and the washings were added to the irradiation vial. Blanks were prepared in an identical manner, except high purity water was used instead of seawater. The samples, blanks and appropriate standards $(10 \mathrm{ml}$ in $15 \mathrm{ml}$ irradiation vials) are neutron activated for 1 hour in a flux of $2 \times 10^{12} \mathrm{n} / \mathrm{cm}^{2} / \mathrm{sec}$. After irradiation, the sample or blank was quantitatively transferred to a vessel that contained $1 \mathrm{ml}$ of mercury carrier. The solution was brought to $\mathrm{pH} \mathrm{l-2}$ with ammonia liquor and $5 \mathrm{ml}$ of tin (II) chloride were added. The precipitate which formed was isolated by centrifugation. The supernate was discarded and the precipitate was dissolved in 5-10 $\mathrm{ml}$ of aqua regia. Copper carrier ( $1 \mathrm{ml}$ ) was added to the solution, the $\mathrm{pH}$ was adjusted as above and precipitation with tin (II) was repeated. This precipitate was collected by filtration, and dissolved in aqua regia and the solution was adjusted to $\mathrm{pH} 7$ with ammonia liquor. Hydrogen sulfide gas was bubbled through the solution for 30 The sulfide precipitate was collected on a Milipore filter and counted.

Comparators, after addition of $1 \mathrm{ml}$ of mercury carrier, were precipitated directly as the sulfide and counted.

The 77-KeV $\gamma$-ray of $197 \mathrm{Hg}$ was measured one week after the irradiation with a NaI(TI) detector coupled to a pulseheight analyzer.

After the radioactivity measurement the mercury sulfide was dissolved in $2 \mathrm{ml}$ of aqua regia and diluted to $25 \mathrm{ml}$ with water. The atomic absorptivity of this solution was compared to that of a mercury standard to obtain the carrier yield. The yield is $81.1+9.8 \%$ for 12 determinations and the sensitivity is 4 nanograms of $\mathrm{Hg}$. 


\section{Mercury Procedure III}

Robertson (unpublished data, 1972) has developed a very simple neutron activation procedure for measuring mercury in seawater. Seawater samples (stored at $\mathrm{pH} \approx 1.5$ to prevent $\mathrm{Hg}$ losses by adsorption onto container walls) of 200 to $1000 \mathrm{ml}$ are adjusted to $\mathrm{pH} \simeq 3.5$ with $\mathrm{NH}_{4} \mathrm{OH}$, warmed to about $60^{\circ} \mathrm{C}$ and $20 \mathrm{ml}$ of $1 \%$ thionalid is added. The seawater is chilled in a refrigerator and the thionalid crystals (containing co-crystallized $\mathrm{Hg}$ ) are collected on a membrane filter, washed with high purity water and encapsulated in polyethylene irradiation vials. Blanks are prepared in an identical manner, using high purity water instead of seawater. The samples, blanks and standards are neutron activated for 5 to 8 hours in a flux of about $5 \times 10^{12} \mathrm{n} / \mathrm{cm}^{2} / \mathrm{sec}$. Several weeks after. the irradiation the samples, blanks and standards are transferred into new vials and counted in the same geometries on a. Ge $(\mathrm{Li})$ diode detector to measure ${ }^{20}{ }^{3} \mathrm{Hg}$. The recovery of $\mathrm{Hg}$ is quantitative and the sensitivity is about 5 nanograms.

\section{Silver Procedure I}

The exact same thionalid co-crystallization procedure described above (Mercury Procedure III) is used for determining Ag in seawater, since Ag is also quantitatively co-crystallized from seawater by thionalid. Sensitivity can be improved by directly counting the samples on a dual coincidence gamma-ray spectrometer described in Section V- Gamma-Ray spectrometry, to measure the multiple coincidence gamma-rays from $110 \mathrm{~m}_{\mathrm{Ag}}$. The sensitivity is about $0.001 \mathrm{\mu g} \mathrm{Ag/l}$.

\section{Silver Procedure II}

Schutz and Turekian (1965b) have determined Ag in seawater by neutron activating. freeze-dried sea salts (from $75 \mathrm{ml}$ of seawater) and appropriate Ag standards for two days in a flux greater than $10^{13} \cdot \mathrm{n} / \mathrm{cm}^{2} / \mathrm{sec}$. After several weeks the irradiated salts are dissolved in $25 \mathrm{ml}$ of water and $1 \mathrm{ml}$ of concentrated $\mathrm{HCl}$, silver carrier is added and the solution heated to coagulate the AgCl precipitate. The precipitate is centrifuged, washed with dilute nitric acid and then treated with concentrated nitric acid, diluted with water and then dissolved in ammonium hydroxide. The solution was scavenged twice with iron, and silver was finally precipitated by the addition of nitric acid. It was filtered, dried and weighed as silver chloride. The precipitate was redissolved and $110 \mathrm{~m}_{\mathrm{Ag}}$ measured by gammaray spectrometry. 


\section{Arsenic Procedure I}

Robertson (1972 unpublished work) has measured arsenic in seawater by an $\mathrm{Fe}(\mathrm{OH})_{3}$ coprecipitation technique. To $35 \mathrm{ml}$ of seawater in $50 \mathrm{ml}$ plastic conical centrifuge tubes is added $5 \mathrm{mg}$ of $\mathrm{Fe}$ (III) carrier, followed by enough dilute $\mathrm{NH}_{4} \mathrm{OH}$ to just precipitate the $\mathrm{Fe}(\mathrm{OH})_{3}$. The precipitate is centrifuged and thoroughly washed twice with two $15 \mathrm{ml}$ portions of high purity water to remove $\mathrm{Na}$ and then transferred into small polyethylene irradiation vials and slowly evaporated to dryness. Blanks are prepared in the same manner using $35 \mathrm{ml}$ of high purity water instead of seawater. The samples, blanks and standards $10.3 \mathrm{gm}$ NBS orchard leaf, As content 10.1 $\mu \mathrm{g} / \mathrm{gm})$ are neutron irradiated for 5 to 8 hours in a flux of about $5 \times 10^{12} \mathrm{n} / \mathrm{cm}^{2} / \mathrm{sec}$. Two or three days after the irradiation the $\mathrm{Fe}(\mathrm{OH})_{3}$ is dissolved in a 10:1 mixture of nitric-hydrochloric acids and transferred into new counting vials and counted for 10-20 minutes each on a $\mathrm{Ge}(\mathrm{Li})$ diode detector to directly measure the ${ }^{76}$ As 559 $\mathrm{KeV}$ gamma ray. Some ${ }^{82} \mathrm{Br}(554 \mathrm{KeV})$ and $122 \mathrm{Sb}$ (564 KeV) are present, but are easily resolved by the Ge(Li) detector. The orchard leaf standards are counted on the Ge(Li) detector in an identical geometry to quantify the measurements. The yield is quantitative and the sensitivity is about $0.08 \mu \mathrm{g}$ As/l.

\section{Arsenic Procedure II}

Ray and Johnson (1972) have used the thionalide preconcentration technique to separate As from seawater prior to neutron activation. To $250 \mathrm{ml}$ of seawater is added $1 \mathrm{ml}$ of $5 \%$ ascorbic acid and the sample is heated just to boiling. The sample is allowed to cool for 10 minutes and $0.5 \mathrm{ml}$ of ascorbic acid is added and cooled to room temperature. Ten $\mathrm{mI}$ of $5 \mathrm{~N} . \mathrm{H}_{2} \mathrm{SO}_{4}$ is added followed by $2 \mathrm{ml}$ of 28 thionalid in acetone. Stir 5 minutes, wait 10 minutes and then bring solution just to boiling and boil very slowly for 30 minutes to remove acetone. Remove from heat and cool overnight. Collect thionalide crystals (containing co-crystallized As) on membrane. filters, rinse with $300 \mathrm{ml}$ of deionized water and encapsule wet filter in a polyethylene vial. Blanks are prepared by using deionized water instead of seawater. The samples, blanks and standards are neutron irradiated for 7 hours in a flux of $10^{12} \mathrm{~m} / \mathrm{cm}^{2} / \mathrm{sec}$. One day after the irradiation count the samples, blanks and standards on a $\mathrm{Ge}(\mathrm{Li})$ diode detector to measure the ${ }^{76} \mathrm{As} 559 \mathrm{KeV}$ gamma ray. Ray and Johnson (1972) report that serious losses (up to $70 \%$ in 1 week) occur by adsorption of As from seawater onto polyethylene storage containers, even when the seawater is acidified with $9 \mathrm{ml}$ of concentrated $\mathrm{HCl} / 1$ of seawater. However, Robertson (1972 unpublished results), using radio-arsenate and arsenite tracers, observed no losses of arsenic from seawater onto poly- 
ethylene container surfaces in both acidified and unacidified samples. E. A. Crecelius (1972 unpublished results, $U$. of Washington) has studied the loss of arsenic added to seawater and lake water as As-74 arsenate. Tests were made with (1) the waters acidified to a $\mathrm{pH}$ of 1 with $\mathrm{HCl}$ and stored at $20^{\circ} \mathrm{C},(2)$ acidified and frozen, (3) unacidified and frozen, and (4) stored unacidified at $20^{\circ} \mathrm{C}$. Losses of only $1-14 \%$ were found with polyethylene and pyrex containers over a two month period. Portman and Riley (1964) found polyethylene, pyrex and soda glass absorb 6,6 and 16\%, respectively of arsenate added to unacidified seawater.

\section{Copper Procedure I}

Slowey and Hood (1971) have modified the procedure of Rona, et al (1962), for determining ionic and organic forms of $\mathrm{Cu}$ in seawater. The seawater samples are oxidized for 5 minutes by reflux digestion with $10 \mathrm{ml}$ each of $0.1 \mathrm{~N}$ potassium persulfate and $0.4 \mathrm{~N} \mathrm{H}_{2} \mathrm{SO}_{4}$. The solution is cooled, neutralized to a pH of 5.5 to 6.5 and $2 \mathrm{ml}$ of $2 \%$ sodium diethyldithiocarbamate in water is added and mixed. Twenty $\mathrm{ml}$ of chloroform is added and the solution shaken for 15 minutes. Three extractions are made and the combined chloroform is scrubbed by shaking with high purity water. The metal carbonate salt is decomposed with three $15 \mathrm{ml}$ portions of $1 \mathrm{~N}$ $\mathrm{HNO}_{3}$ and the solution is evaporated to a small volume, transferred to $1.5 \mathrm{ml}$ polyethylene vials, evaporated to dryness, heat-sealed and neutron activated with appropriate standards for one hour in a flux of $2 \times 10^{12}$ $\mathrm{n} / \mathrm{cm}^{2} / \mathrm{sec}$. After neutron activation the copper is separated by sorption on Dowex 1x8 (200 mesh) anion exchange resin from $12 \mathrm{~N} \mathrm{HCl}$. The resin is washed with $12 \mathrm{~N} \cdot \mathrm{HCl}$ and ${ }^{64} \mathrm{Cu}$ and ${ }^{55} \mathrm{Mn}$ are eluted together using $2.5 \mathrm{~N} \mathrm{HCl}$. The ${ }^{64} \mathrm{Cu}$ and ${ }^{56} \mathrm{Mn}$ in the sample and standards are measured by gamma-ray spectrometry. The method is nearly_quantitative and the sensitivity for $\mathrm{Cu}$ is $3 \times 10^{-\frac{1}{3}} \mu \mathrm{g}$.

No other methods for measuring $\mathrm{Cu}$ in seawater by neutron activation analysis have been reported in the literature, but a convenient method for concentrating $\mathrm{Cu}$ from large volumes of seawater is by sorption on Chelex-100 chelating resin (Riley and 'l'aylor, 1968). Copper is quantitatively retained on Chelex-100 at a pH of 7.6 and eluted with $2 \mathrm{~N} \mathrm{HNO}_{3}$, and it may be possible to measure $\mathrm{Cu}$ without any further separation. If further radiochemical purity is required, a postirradiation separation employing a suitable solvent extraction procedure could be readily accomplished. 


\section{Selenium Procedures}

The only method for measuring se in seawater by neutron activation analysis is that reported by Schutz and Turekian (1965b). Seventy-five ml samples of seawater are freeze-dried and the salts and appropriate standards are neutron activated for 2 days in a flux greater than $10^{13} \mathrm{n} / \mathrm{cm}^{2} / \mathrm{sec}$. Several weeks after the irradiation the salts are dissolved in dilute $\mathrm{HCl}$ and $\mathrm{Se}$ carrier is added. The Se is then precipitated as the sulfide by bubbling $\mathrm{H}_{2} \mathrm{~S}$ gas into the solution. The precipitate is centrifuged and washed with distilled water and the precipitate is dissolved in $\mathrm{HNO}_{3}$ and reprecipitated as se metal by bubbling $\mathrm{SO}_{2}$ into the solution. The Se metal is separated from large amounts of ${ }^{35} \mathrm{~S}$ by placing the se precipitate in a quartz tube with one end closed and heating the tube to drive the selenium out of the tube into a weighed pyrex counting vial. The Se is oxidized to $\mathrm{SeO}_{2}$ with $\mathrm{HNO}_{3}$, dried and weighed. The $\mathrm{SeO}_{2}$ is then dissolved in water and brought to a standard volume for counting by gamma-ray spectrometry. Selenium concentrations of 0.05 to $0.1 \mu \mathrm{g} / 1$ were reported using this method.

This method is rather tedious and time consuming and perhaps a more convenient method could be easily developed. Chau and Riley (1965) found that Se(IV) could be coprecipitated from seawater with $\mathrm{Fe}(\mathrm{OH})_{3}$ with $\simeq 95$ 응 efficiency in $\mathrm{pH}$ 4-6 range. This may be a convenient method for preconcentrating se from large volumes of seawater (0.2 to 2 liters) prior to neutron activation. If postirradiation separations are necessary, precipitations with $\mathrm{H}_{2} \mathrm{~S}$ or $\mathrm{SO}_{2}$ could be employed. Preconcentration of Se from 0.2 to 2 liters of seawater prior to neutron activation is recommended to give the necessary sensitivity and to eliminate the high radiation levels produced by neutron activation of sea salts.

\section{Cadmium Procedure}

No method for measuring $\mathrm{Cd}$ in seawater by neutron activation analyses has been reported in the literature. However, cd could be preconcentrated from large volumes uf sedwaler by the Chelex 100 mothod of Riley and Taylor (1968). Cadmium is quantitatively retained on Chelex-100 chelating resin at $\mathrm{pH} 7.6$ and eluted with $2 \mathrm{~N} \mathrm{HNO}_{3}$. The $2 \mathrm{~N} \mathrm{HNO}_{3}$ could be evaporated, neutron activated and $115 \mathrm{Cd}$ $(\overline{5} 4 \mathrm{hrs})$ separated by anion exchange from strong $\mathrm{HCl}$ solutions or by sulfide precipitations.

It may be that the thionalid preconcentration procedures described for $\mathrm{Hg}$ and Ag would be applicable for Cd under the proper $\mathrm{pH}$ conditions. 


\section{Chromium Procedures}

Schutz and Turekian (1965b) have developed a method for measuring $\mathrm{Cr}$ in seawater by neutron activation analysis. but the method is tedious and is not recommended as a routine method. Stanford (1971) reported a method based on extraction of $\mathrm{Cr}$ (VI) by methyl isobutyl ketone after acidification with hydrochloric acid. For analysis of total $\mathrm{Cr}$, any $\mathrm{Cr}$ (III) present is oxidized to $\mathrm{Cr}$ (VI) with potassium peroxydisulfate and a copper (II) catalyst. Fukai (1967) and Chuecas and Riley (1966) reported that Cr(III) could be preconcentrated from seawater by coprecipitation with $\mathrm{Fe}(\mathrm{OH})_{3}$. Any $\mathrm{Cr}(\mathrm{VI})$ present must be reduced to $\mathrm{Cr}$ (III) with sodium sulfite in acid medium to measure total $\mathrm{Cr}$ concentrations. The methods of Stanfield (1971) and Fukai (1967) have both used the diverse chemistries of $\mathrm{Cr}$ (III) and $\mathrm{Cr}$ (VI) in their methods as a measure of the chemical species naturally present in seawater. After $\mathrm{Cr}$ has been preconcentrated from a large volume $(0.5$ to 2 liters) of seawater, the concentrate can be neutron activated and postirradiation separations as outlined by Pijck (1964) can be performed.

\section{Marine Organisms}

1. Instrumental Analysis

INAA is particularly applicable for the measurement of trace metals in marine organisms. Approximately 18 trace elements can be measured in most marine organisms by INAA, including the potential pollutant elements $\mathrm{Hg}, \mathrm{Ag}, \mathrm{As}$, $\mathrm{Sb}, \mathrm{Zn}$ and Se (Haller, et al 1969; Morrison and Potter, 1972; Robertson, et al 1972). Cadmium and chromium are present in most biological tissues at concentrations just under their INAA detection limits, but can be measured in some specimens when their concentrations exceed about 1 and $0.1 \mu \mathrm{g} / \mathrm{gm}$ dry weight, respectively. The ultimate sensitivities achieved by INAA for many elements are limited by the high concentrations of the pure beta-emitter ${ }^{32} \mathrm{P}$ $(14$ d) formed in the activated samples. The bremsstrahlung radiation produced from the ${ }^{32} \mathrm{P}$ creates an instrumental dead time problem when biological samples receive too great a neutron exposure.

In practice, the. INAA of biological tissue samples consists of encapsuling a 10-1000 $\mathrm{mg}$ sample of dried tissue (fresh to dry weight ralius should be obtained) in a 
cleaned plastic irradiation vial and neutron irradiaing the sample and appropriate standards to an inteqral thermal neutron exposure of about $10^{17} \mathrm{n} / \mathrm{cm}^{2}$. After the irradiation, the samples and standards are transferred into standard counting geometries and counted on a $\mathrm{Ge}(\mathrm{Li})$ detector at optimum times following the irradiation to measure both short- and long-lived neutron activated products. Figures 8 and 9 show some typical gamma-ray spectra of neutron activated marine organism muscle tissue, illustrating the neutron activation products which can be measured after both a short and long storage period between the irradiation and counting.

As in the case for natural waters, two to four days out of the reactor the major neutron activation products are ${ }^{24} \mathrm{Na}$ and ${ }^{82} \mathrm{Br}$, but normally high enough concentrations of ${ }^{42} \mathrm{~K}$ and ${ }^{76} \mathrm{As}$ are present for accurate measurements. Some ${ }^{64} \mathrm{Cu}$ is also present, but since the main radiation emitted during its radioactive decay is the $51 \mathrm{l} \mathrm{KeV}$ positron annihilation photons, it is safer to radiochemically separate the ${ }^{64} \mathrm{Cu}$. Several other short-lived radionuclides in activated biological tissue are also positron emitters. When cadmium concentrations in the biological tissue are over $1 \mathrm{\mu g} / \mathrm{gm}$ dry weight, $115 \mathrm{Cd}(54 \mathrm{hr})$ can be instrumentally measured from its $528 \mathrm{KeV}$ gamma-ray or the $335 \mathrm{KeV}$ gamma-ray from the $115 \mathrm{~m}$ In isomer.

After the samples have been out of the reactor for about two weeks, most of the ${ }^{24} \mathrm{Na}$ and much of the ${ }^{82} \mathrm{Br}$ have decayed to tolerable levels and a new suite of long-lived neutron activation products can be instrumentally measured, including $\mathrm{Rb}, \mathrm{Cs}, \mathrm{Fe}, \mathrm{Zn}, \mathrm{Ag}, \mathrm{Co}, \mathrm{Cr}, \mathrm{Hg}, \mathrm{Se}, \mathrm{Sb}$ and $\mathrm{Sc}$. Table 4 lists the elements which can usually be measured by INAA, and compares their detection limits by this method with the typical concentration ranges normally found in marine biological tissue. As shown in Table 4 the INAA detection limits for most of these elements are 
GAMMA-RAY SPECTRUM OF NEUTRON ACTIVATED PINK SHRIMP TAIL MUSCLE TISSUE (IDOE 63)

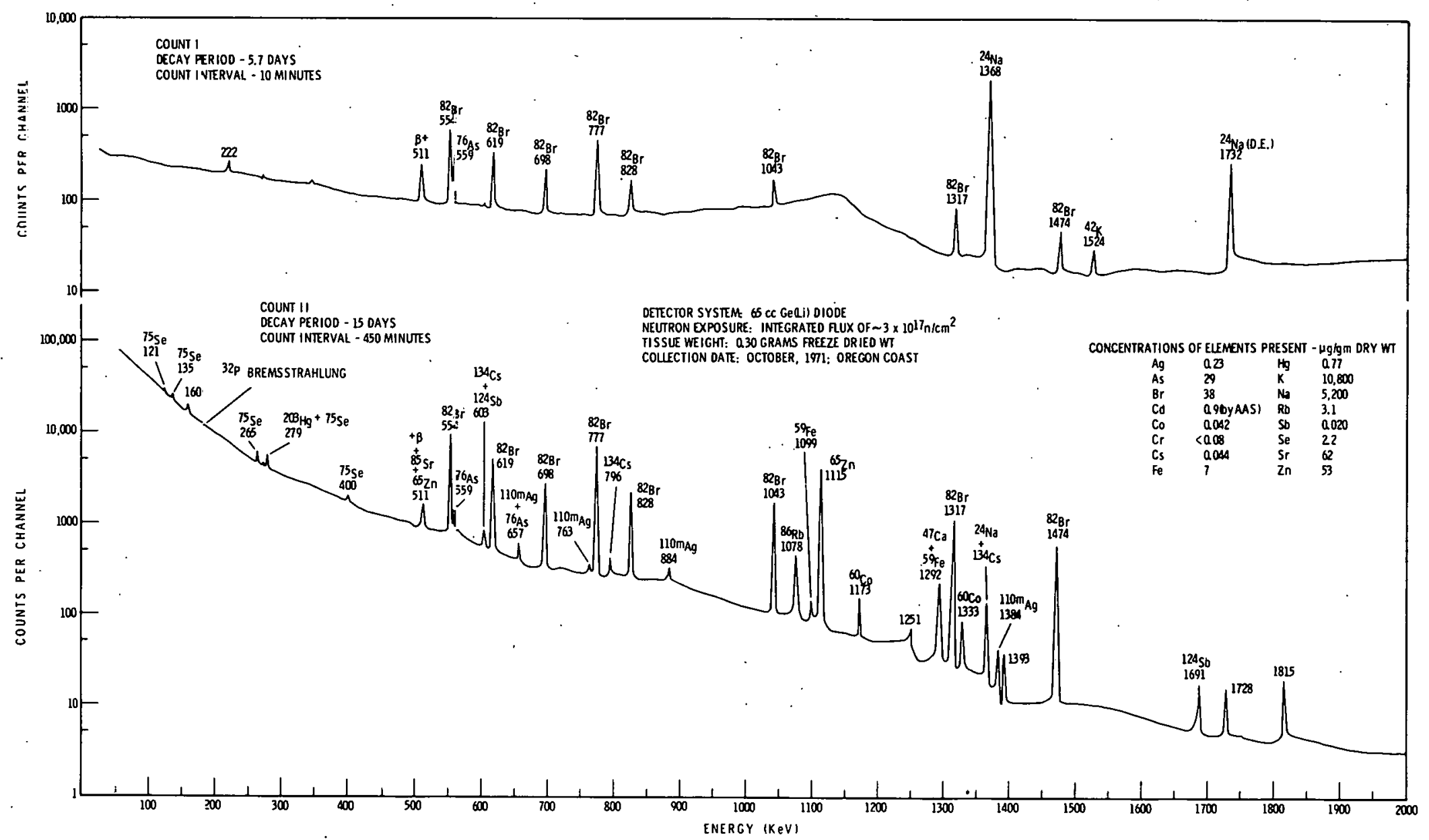




\section{FIGURE 9}

GAMMA-RAY SPECTRUM OF NEUTRON ACTIVATED LEMON SOLE MUSCLE TISSUE (IDOE 59)

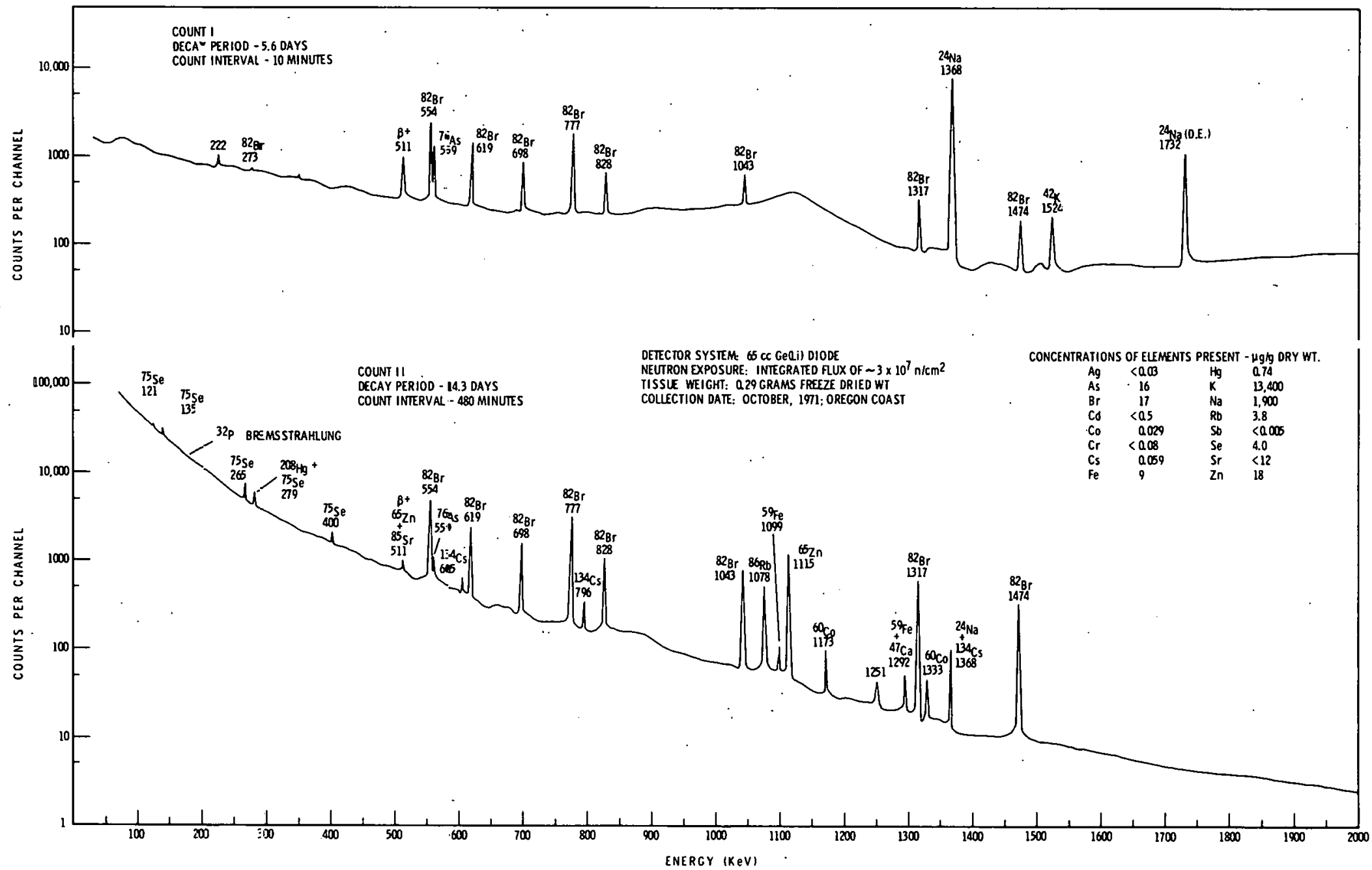


TABLE 4

ESTIMATED DETECTION LIMITS OF INSTRUMENTAL NEUTRON ACTIVATION ANALYSIS OF BIOLOGICAL MATERIAL ( $\mu \mathrm{g} / \mathrm{g}$ DRY TISSUE)

\begin{tabular}{|c|c|c|c|}
\hline ELEMENT & $\begin{array}{l}{ }^{*} \text { TYP } \\
\text { IN }\end{array}$ & $\begin{array}{l}\text { ICAL CONCENTRATION } \\
\text { MARINE ORGANISMS }\end{array}$ & DETECTION LIMIT * \\
\hline $\mathrm{Na}$ & & $500-1500$ & 0.05 \\
\hline $\mathrm{K}$ & & $1000-30,000$ & 20 \\
\hline $\mathrm{Pb}$ & & $0.5-8$ & 1 \\
\hline Cs & & $0.02-0.4$ & $0.0001^{\dagger}$ \\
\hline $\mathrm{Fe}$ & & $1-500$ & 2 \\
\hline $\mathrm{Zn}$ & & $10-200$ & 0.5 \\
\hline $\mathrm{Br}$ & & $10-200$ & 0.05 \\
\hline As & & $<1-50$ & 0.3 \\
\hline $\mathrm{Cd}$ & & $<0.1-10$ & 1 \\
\hline $\mathrm{Ag}$ & & $<0.001-5$ & $0.001^{\dagger}$ \\
\hline Co & & $0.001-0.5$ & $0.001^{\dagger}$ \\
\hline $\mathrm{Cr}$ & & $<0.02-1$ & 0.02 \\
\hline $\mathrm{Hg}$ & & $0.05-5$ & 0.02 \\
\hline $\mathrm{Se}$ & & $0.5-50$ & 0.05 \\
\hline $\mathrm{Sb}$ & & $0.0001-0.05$ & $0.0001^{\dagger}$ \\
\hline Sc & & $0.00001-0.002$ & $0.00005^{\dagger}$ \\
\hline * 7 & \multicolumn{3}{|c|}{$\begin{array}{l}\text { Typical Ranges in various tissues, with the low ranges } \\
\text { usually associated with muscle and high ranges with liver. }\end{array}$} \\
\hline 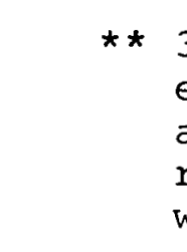 & \multicolumn{3}{|c|}{$\begin{array}{l}300 \mathrm{mg} \text { of freeze-dried tissue; integral thermal neutron } \\
\text { exposure of } 3 \mathrm{x} 10^{17} \mathrm{n} / \mathrm{cm}^{2} ; 20 \text { min. and } 1000 \mathrm{~min} \text {. Counts } \\
\text { after decay periods of } 3 \text { to } 5 \text { days and } 20 \text { to } 30 \text { days, } \\
\text { respectively } 20 \text { to } 40 \mathrm{cc} \mathrm{Ge}(\mathrm{Li}) \text { diode detection, except } \\
\text { where specified. }\end{array}$} \\
\hline $\begin{array}{r}+ \\
5 \\
5 \\
5 \\
5\end{array}$ & \multicolumn{3}{|c|}{$\begin{array}{l}\text { Detection limits obtained by dual, coincidence. NaI(Tl) } \\
\text { spectrometry. Detection limits obtained by Ge ( } \mathrm{Li}) \\
\text { spectrometry for these five elements are approximately } \\
5-\text { to } 10 \text {-fold higher. }\end{array}$} \\
\hline
\end{tabular}


sufficiently low to permit their measurement in almost any type of biological matrix. Cadmium, $\mathrm{Ag}, \mathrm{Cr}$, and $\mathrm{Sb}$ are frequently present in organisms at concentrations near or just below their INAA detection limits, and if necessary, postirradiation radiochemical separations of their neutron activation products can be performed by rather simple group chemical separations.

2. Analysis of Elements Requiring Preconcentration or Postirradiation Separations

The only elements which cannot normally be measured in marine biological tissue by INAA are $\mathrm{Cd}, \mathrm{Cr}, \mathrm{Cu}$ and frequently $\mathrm{Ag}$ and $\mathrm{Sb}$. However, these elements can be easily measured by neutron activation followed by radiochemical separations.

\section{Cadmium Procedures}

Many procedures for determining cd in biological tissue have been reported: Lieberman and Kramer (1970); Das and de Vries (1971); Livingston, et al (1970); Ljunggren, et al (1970); Edgington and Lucas (1970); Samsahl, et al. (1968); Morrison and Potter (1972).

Biological tissues have been prepared for neutron irradiation in various ways--some investigators irradiated fresh material, others freeze-dried or ashed samples. Sample decomposition after irradiation has generally been by digestion with $\mathrm{H}_{2} \mathrm{SO}_{4}$, with $\mathrm{K}_{2} \mathrm{~S}_{2} \mathrm{O}_{8}$ or $\mathrm{HNO}_{3}$ addition to speed dissolution. The samples ashed prior to irradiation are dissolved in concentrated HCl.

One. Cd separation scheme uses the extraction with dithizone/chloroform solution as the key separation step (Lieberman and Kramer - 1970). Following $\mathrm{H}_{2} \mathrm{SO}_{4} /$ $\mathrm{K}_{2} \mathrm{~S}_{2} \mathrm{O}_{8}$ digestion of the samples, the $\mathrm{pH}$ is adjusted to 1 to 2 and gross radioactive interferences are extracted into the dithizone layer while Cd stays in aqueous layer. Subsequently, the $\mathrm{pH}$ is adjusted to 13 to 14 and $C d$ is then extracted into the dithizone layer. Yields are determined by adding $109 \mathrm{Cd}$ spike to each acid digestion sample.

Four other separation schemes (Morrison and Potter, 1972; Livingston, et al, 1970; Edgington and Lucas, 1970; Samsahl, et al, 1968) use anion exchange as the key to Cd separation. Cadmium forms very strong chloro-complexes which persist until very low HCl 
concentrations and the complexes are firmly bound to Dowex 1 or 2, or Amberlite IRA-400 anion exchange resins in the $\mathrm{Cl}$ form. The great majority of other elements and radioactivities can be eluted from the columns before the Cd. The cd activity has been measured both on the resin directly and following elution and subsequent precipitation. Samsahl, et al (1968) and Bowen (1967) use several precipitation and dissolution steps involving cas to remove cd from interfering isotopes.

Copper Procedure I

Although the $511 \mathrm{KeV}$ positron annihilation radiation from ${ }^{64} \mathrm{Cu}$ can usually be detected instrumentally in neutron activated biological tissue, other short-lived radionuclides, including $2{ }^{4} \mathrm{Na}$, are present which also contribute to positron annihilation radiation. Therefore, the ${ }^{64} \mathrm{Cu}$ should be radiochemically separated from interfering radionuclides, principally ${ }^{24} \mathrm{Na}$. Four general separation schemes have been devised for $\mathrm{Cu}$ based on the insolubility of its sulfide, the solvent extractability of its organic chelates, its cation exchange behavior and its electrodeposition properties.

A rapid and simple method developed by Hahn, et al (1968), consists of digesting the biological tissue in nitric acid, dissolving the residue in $4 \mathrm{ml}$ of $1 \mathrm{~N}$ nitric acid, transferring the solution to a separatory funnel containing $2 \mathrm{ml}$ of $0.1 \mathrm{~N} \mathrm{HCl}$ and extracting ${ }^{64} \mathrm{Cu}$ with $5 \mathrm{ml}$ of $0.01 \%$ dithizone in $\mathrm{CCl}_{4}$ by shaking for 2 minutes. The $\mathrm{CCl}_{4}$ is transferred to a polyethylene counting vial and ${ }^{64} \mathrm{Cu}$ determined by gamma-ray spectrometry .

\section{Copper Procedure II}

Bird, et al (1969), have measured $\mathrm{Cu}$ in biological tissue by NAA after removal of ${ }^{24} \mathrm{Na}$ by retention on hydrated antimony pentoxide (HAP). The neutron activated tissue sample is digested in fuming $\mathrm{HNO}_{3}$ $\mathrm{H}_{2} \mathrm{SO}_{4}, 0.1 \mathrm{mg}$ of $\mathrm{Cu}$ carrier is added and the solution is cooled and passed through a $0.5 \mathrm{gm}$ column of HAP that had been preconditioned with $9 \mathrm{~N} \mathrm{HNO}_{3}$. The column effluent (and $9 \mathrm{~N} \mathrm{HNO}_{3}$ rinses) is collected and counted to measure ${ }^{64} \mathrm{Cu}$. Some ${ }^{54} \mathrm{Mn}$ is present, but can be manually stripped from the gamma-ray spectra.

\section{Copper Procedure III}

Merlini, et al (1970), measure Cu in biological tissue by NAA after separating ${ }^{64} \mathrm{Cu}$ on columns of cuprous chloride or cupric sulfide. The irradiated tissue sample is digested in hot $\mathrm{HNO}_{3} \mathrm{HF}$ and brought to $6 \mathrm{M}$ $\mathrm{HClO}_{4}$ or $1 \mathrm{M} \mathrm{H}_{2} \mathrm{SO}_{4}$ and the solution is passed through a $7 \mathrm{~mm}$ diameter by $30 \mathrm{~mm}$ long column of cuprous chloride or cupric sulfide. The column is rinsed with $15 \mathrm{ml}$ of 
the same acid and counted directly by gamma-ray spectrometry. Copper is retained on the column, while most interfering radionuclides are eluted. Only $\mathrm{Au}, \mathrm{Hg}, \mathrm{Sb}, \mathrm{Se}, \mathrm{Br}, \mathrm{W}$ and $\mathrm{I}$ are wholly or partially retained on the column, but do not prevent the measurement of the $511 \mathrm{KeV}{ }^{64} \mathrm{Cu}$ activity.

\section{Copper Procedure IV}

Battistone and Lofberg (1970) quantitatively determine $\mathrm{Cu}$ in biological tissues by NAA utilizing an electrodeposition technique. The activated samples are digested in $\mathrm{HNO}_{3}$ in the presence of $\mathrm{Cu}$ carrier, and the digest taken just to dryness. The residue is dissolved in $1 \mathrm{ml}$ of concentrated $\mathrm{HNO}_{3}$ and rinsed into a $25 \mathrm{ml}$ polyethylene beaker with 3 to $5 \mathrm{ml}$ portions of the electroplating solution (10\% sodium tartarate, 1\% hydrazine hydrochloride, $1 \%$ sodium hydroxide, and $0.5 \%$ urea, prepared weekly). The $\mathrm{Cu}$ is electrodeposited onto cylindrical platinum electrodes at 2.5 volts and an initial current of 2.75 amperes for 45 minutes while stirring with a Teflon-coated magnetic stirring bar. The electrodes are removed while the current is still on and rinsed with 95\% ethyl alcohol. The electrodes are then directly counted by gamma-ray spectrometry, or the ${ }^{64} \mathrm{Cu}$ is dissolved off with several $\mathrm{ml}$ of $8 \mathrm{~N} \mathrm{HNO}_{3}$ which is then counted.

\section{Silver Procedures}

Silver can be conveniently separated from neutron activated biological tissue by the method of Merlini, et al (1970). After digestion of the irradiated tissue in hot $\mathrm{HNO}_{3}-\mathrm{HF}$, the solution is brought to $6 \mathrm{M} \mathrm{HClO}_{4}$ and passed through a.7 mm diameter by $30 \mathrm{~mm}$ long column of cuprous chloride. Over 99\% of the Ag is retained on the column, while interfering radionuclides are eluted with $15 \mathrm{ml}$ of the same acid. The column can then be counted directly to measure the li $0 \mathrm{~m}_{\mathrm{Ag}}$ by gamma-ray spectrometry. Only $\mathrm{Cu}, \mathrm{Au}, \mathrm{Se}, \mathrm{W}, \mathrm{I}, \mathrm{Hg}, \mathrm{Pa} ; \mathrm{Sn}$ and $\mathrm{Sb}$ are wholly or partially retained on the column, but do not interfere with the measurement of $110 \mathrm{~m}_{\mathrm{Ag}}$. Bromine-82, which is also retained on the column, would normally interfere, but the digestion step with $\mathrm{HNO}_{3}$ should volatizile most of the $\mathrm{Br}$.

Once the biological tissue sample has been adequately digested by acid dissolution, the same Ag separations as used for seawater can also be employed here.

\section{Antimony Procedure}

Antimony can be determined by INAA in most biological tissue by measuring the $1696 \mathrm{KeV}$ gamma-ray from ${ }^{12}{ }^{4} \mathrm{Sb}$. The sensitivity for measuring $\mathrm{Sb}$ is not limited due to interferences from other neutron activation products, but is limited by the dead-time to the Ge(Ii) gamma-ray spectrometer caused by the high levels of the ${ }^{32} \mathrm{P}$ 
bremsstrahlung. Greater sensitivity could be achieved for $\mathrm{Sb}$ if a larger tissue sample were neutron irradiated for a longer time, and the activated tissue sample was cncased in some material, such as $0.7 \mathrm{~mm}$ thick $\mathrm{Pb}$, to attenuate the ${ }^{32} \mathrm{P}$ bremsstrahlung.

An alternative approach would be to use the rapid separation scheme of Merlini, et al (1970), whereby $12.2-124 \mathrm{Sb}$ is retained on a cuprous chloride column from $1 \underline{\mathrm{M}} \mathrm{H}_{2} \mathrm{SO}_{4}$.

\section{Chromium Procedures}

After digestion of neutron activated biological tissue samples, Cu may be separated by the solvent extraction procedure described in the section on seawater analysis.

Bowen (1964) has also developed a separation scheme for measuring $\mathrm{Cr}$ in biological tissue by NAA. After digestion of the irradiated samples in $\mathrm{HNO}_{3}-\mathrm{H}_{2} \mathrm{SO}_{4}$ with $\mathrm{Cr}$ carrier added, and subsequently with $\mathrm{HCLO}_{4}$, the $\mathrm{Cr}$ is distilled into $10 \mathrm{ml}$ of water from a $\mathrm{HClO}_{4}-\mathrm{H}_{2} \mathrm{SO}_{4}$ solution to which $0.1 \mathrm{gm}$ of $\mathrm{NaCl}$ had been added. The distillation with 2 more portions of $\mathrm{NaCl}$ is repeated. The distillate is next transferred to a separatory funnel and shaken with an equal volume of methyl isobutyl ketone, a few drops of concentrated $\mathrm{HCl}$ being added to improve the extraction. The aqueous layer is discarded and the organic layer is washed with $2 \mathrm{~N} \mathrm{HCl}$, and then shaken twice with $10 \mathrm{ml}$ portions of $\mathrm{NH}_{4} \mathrm{Cl}$. The $\mathrm{NH}_{4} \mathrm{Cl}$ solutions are scavenged with $\mathrm{Fe}(\mathrm{OH})_{3}$. The supernate is made acidic with acetic acid and treated with $2 \mathrm{ml}$ of barium acetate. The $\mathrm{BaCrO}_{4}$ precipitate is coagulated by boiling, centrifuged and dissolved in hot $\mathrm{HCl}$ and reprecipitated at $\mathrm{pH} 6$. The precipitate is washed twice with water, dried, weighed to determine yield and $51 \mathrm{Cr}$ is measured by gamma-ray spectrometry.

The above procedure is quite lengthy and Meloni, et al (1969), have measured $\mathrm{Cr}$ in biological tissue by removing interfering ${ }^{24} \mathrm{Na}$ and $32 \mathrm{P}$. Tissue samples are digested in $\mathrm{HNO}_{3}$ and the solution made $\mathrm{IN}$ in $\mathrm{HNO}_{3}$ and passed through a column of hydrated antimony pentoxide (HAP) to retain ${ }^{24} \mathrm{Na}$. The effluent (and $1 \mathrm{~N} \mathrm{HNO}_{3}$ rinse) is evaporated to about $10 \mathrm{ml}$ and is then passed through a small column of $\mathrm{SnO}_{2}$ which retains the ${ }^{32} \mathrm{P}$. The effluent (and $1 \mathrm{~N} \mathrm{HNO}_{3}$ rinse) is treated with $\mathrm{KClO}_{3}$ to oxidize $\mathrm{Cr}(\mathrm{VI})$ and the solution is passed through a small column of $\mathrm{MnO}_{2}$ to retain $\mathrm{Cr}$. The $\mathrm{MnO}_{2}$ is filtered, dried and counted directly to measure ${ }^{51} \mathrm{Cr}$ by gamma-ray spectrometry.

D. Sediments

1. Instrumental Analysis

Of the various analytical methods available for the determination of elemental concentrations in geological 
materials, neturon activation analysis is one of the most sensitive, selective and reliable. INAA, utilizing high resolution $\mathrm{Ge}(\mathrm{Li})$ detectors, permits the nondestructive measurement of 25 to 30 elemental constituents in geological material, including marine and fresh water sediments (Brunfelt and Steinnes, 1966; Gordon, et al 1968; Robertson, et al 1972). However, most of the elements which can be measured in sediments by INAA are mainly of a geochemical interest and, of the pollutant metals of concern, only $\mathrm{As}, \mathrm{Sb}$ and $\mathrm{Cr}$ can be measured routinely. Mercury and zinc can be measured instrumentally utilizing a special-coincidence-anticoincidence Ge(Li) detector system (Cooper and Perkins, 1972). Utilizing Ge(Li) diode spectrometry and group radiochemical separations, the pollutant elements of interest can be measured (Filby, et al, 1970; Morrison, et al, 1969; Petersion, et al, 1969).

The general scheme for measuring trace elements in sediments by INAA is to weigh dried sediments (10 to $1000 \mathrm{mg}$ ) into cleaned plastic irradiation vials, heat-seal the vials and neutron irradiate the samples, together with appropriate elemental standards encapsulated in an identical geometry as the samples. Elements with shortlived neutron activation products $(2.8$ minutes to several hours) are measured by irradiating the samples in a rabbit facility for several minutes at a thermal neutron flux of 1 to $50 \times 10^{12} \mathrm{n} / \mathrm{cm}^{2} / \mathrm{sec}$, and then counting the samples directly on a Ge(Li) diode detector for 5 to 10 minutes. Elemental standards are identically activated and counted to quantify the concentrations of the elements of interest in the samples. To determine those elements with intermediate half-life activation products (several hours to several days), the identical sediment sample used for the rabbit irradiation, or an aliquot of the same sample, plus elemental standards are neutron irradiated to an integral thermal neutron exposure of about $10^{17} \mathrm{n} / \mathrm{cm}^{2}$. The samples and standards are then 
transferred into new counting containers and counted for 10 to 30 minutes on a Ge(Li) diode detector after 2 to 24 hours decay time. For the measurement of elements with long-lived activation products (several days to several years) the samples and standards are recounted 5 to 15 days later for 60 to 200 minutes.

Some typical gamma-ray spectra of neutron activated deep sea red clay obtained by this method are shown in Figure 10. From the rabbit irradiations and short count it is possible to measure the elements $\mathrm{Al}, \mathrm{V} ; \mathrm{Mn}, \mathrm{Na}$ and $\mathrm{Cl}$. Two to three hours after the long irradiation, the short-lived ${ }^{28} \mathrm{Ai}$ and ${ }^{52} \mathrm{~V}$ have decayed, and it is possible to measure $\mathrm{Na}, \mathrm{K}, \mathrm{Mn}, \mathrm{Cl}, \mathrm{Ba}$ and Dy. After a decay period of about 5 days the elements which can be measured are $\mathrm{Na}, \mathrm{K}, \mathrm{Sc}, \mathrm{Cr}, \mathrm{Fe}, \mathrm{Co}, \mathrm{As}, \mathrm{Br}, \mathrm{Ba}, \mathrm{Cs}$, $\mathrm{La}, \mathrm{Ce}, \mathrm{Sm}, \mathrm{Yb}, \mathrm{Lu}, \mathrm{Hf}$ and $\mathrm{Th}$ (from $23{ }^{3} \mathrm{~Pa}$ ).

The detection sensitivities for these elements which are obtained by INAA are dependent upon the composition of the sediment sample. For example, evaporite types of sediments having high $\mathrm{Na}$ and $\mathrm{Br}$ concentrations would create interferences which would limit the detection serisitivities of a number of elements. On the other hand, very pure calcareous sediments would permit more sensitive trace element analysis because of lower concentrations of interfering elements.

In Table 5, estimates of the detection limits for measuring trace elements in typical coastal or deep sea marine sediments by INAA are shown. The detection limits for most of the elements shown in Table 5 were derived by extrapolating from the INAA detection limits for these elements in the standard geological reference materials W-I and G-2 (Gordon, et al, 1968). These standard rocks have trace element concentration ranges somewhat similar to those observed in marine sediments, and this comparison should give detection limits for marine sediments that are reliable to within an order of magnitude. As indicated 


\section{EIGURE 10}
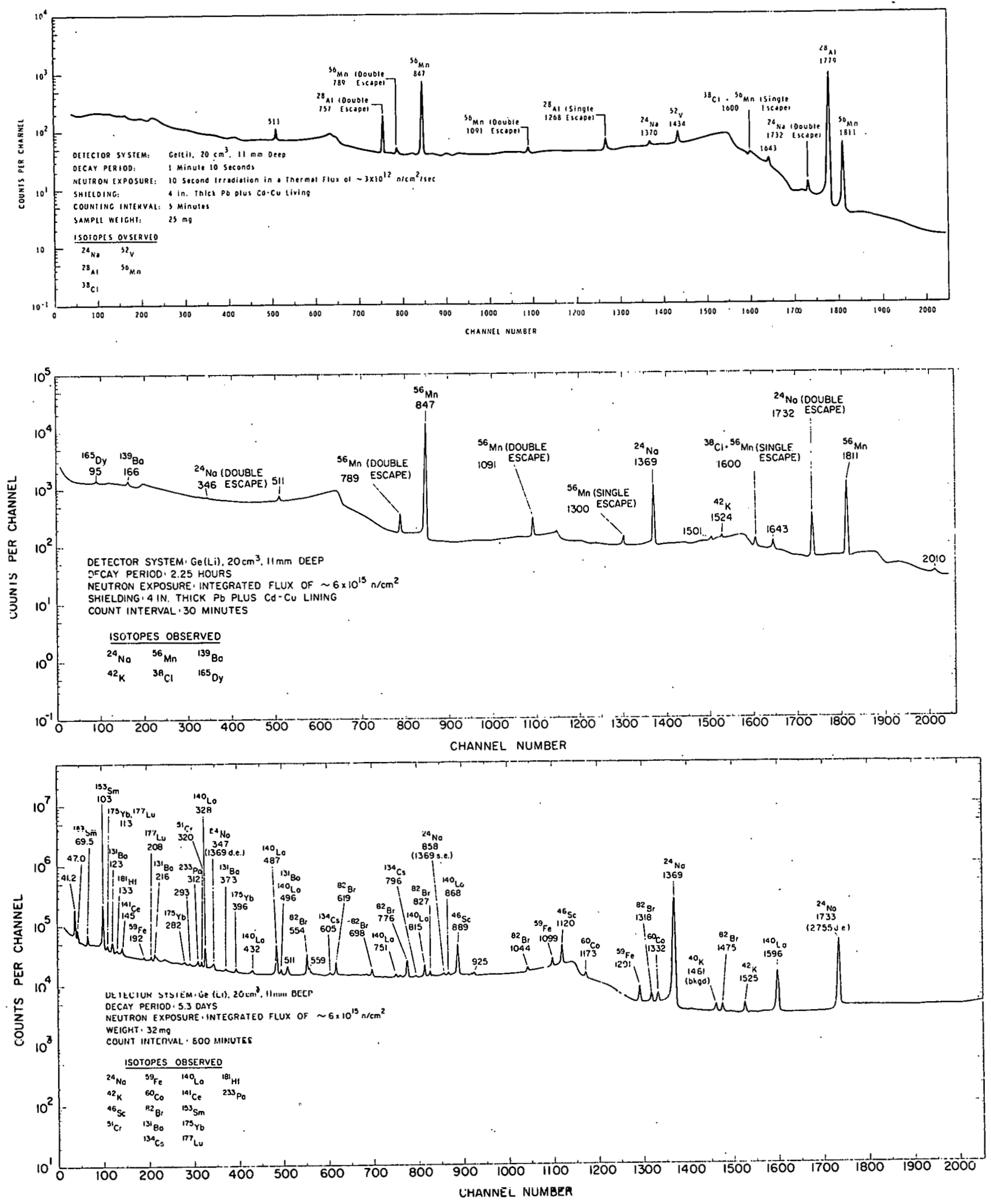

Gamma-Ray Spectra of Neutron Irradiated leep sea Ked Clay Sediment after One Minute, Two Hours and Five Days Decay. 
TABLE 5

ESTIMATFD DETECTION LIMITS FOR THE INAA OF TRACE ELEMENTS IN MARINE SEDIMENTS

\section{Element}

Ag

A1

As

$\mathrm{Ba}$

$\mathrm{Ce}$

c.

Co

$\mathrm{Cr}$

Cs

$\mathrm{Cu}$

Dy

$\mathrm{Eu}$

$\mathrm{Fe}$

$\mathrm{Hf}$

$\mathrm{Hg}$

$\mathrm{K}$

La

$\mathrm{Lu}$

Mn

$\mathrm{Na}$

$\mathrm{Pb}$

$\mathrm{Pb}$

$\mathrm{Sb}$

$\mathrm{Sc}$

$\mathrm{Se}$

$\mathrm{Sm}$

Sn

Sr

$\mathrm{Ta}$

$\mathrm{Tb}$

Th

$\mathrm{V}$

Yb

$\mathrm{Zn}$

$\mathrm{Zr}$
Typical Concentration Ranges in Marine Sediments ( $\mu \mathrm{g} / \mathrm{gm})$

$0.01-0.5$

$10,000-90,000$

$2-20$

$60-8100$

$40-70$

205

$1-200$

$10-200$

$0.3-15$

$10-700$

0.2

$0.2-10$

$20,000-60,000$

$0.1-18$

$0.05-3$

$3000-30,000$

$2-60$

0.2

$100-10,000$

$2000-40,000$

$10-200$

$1-100$

$0.5-15$

$0.2-30$

$0.1-1$

$0.5-30$

$0.5-15$

200-2000

$0.03-3$

$0.1-7$

$0.3-10$

$10-500$

1

$5-4000$

$100-400$
INAA $\frac{\text { Sensitivity }}{(\mu \mathrm{g} / \mathrm{gm})}$

0.1

10

1

100

5

10

0.1

0.8

0.2

1

0.1

0.05

200

0.1

0.5

5000

2

0.1

10

100

$---$

1 **

0.1

0.02

2

0.3

500

100 *

0.01

0.1

0.08

10

0.3

$5 * *$

70

* 100 to $800 \mathrm{mg}$ of aried sediment; samples irradiated at optimum intervals ranging from 1 minute to 6 hours in a flux of $10^{11}$ to $10^{13} \mathrm{n} / \mathrm{cm}^{2} / \mathrm{sec}$ and counted at optimum intervals after the irradiation for 1 minute to 200 minutes; $\mathrm{Ge}(\mathrm{I} i)$ diode detectors, $20 \mathrm{cc}$ to $60 \mathrm{cc}$ volumes.

* * Determined by counting on a coincidence-articoincidence shielded Ge(Li) gamma-ray spectrometer (Cooper and Perkins, 1972). 
in Table 5, INAA possesses the necessary sensitivity to instrumentally measure all of the pollutant elements of interest, except $\mathrm{Ag}, \mathrm{Cd}, \mathrm{Cu}, \mathrm{Se}, \mathrm{Zn}$ and frequently, $\mathrm{Hg}$. The following section outlines methods for the postirradiation separations of the activation products of these elements to give the desired sensitivity for their measurements.

2. Analysis of Elements Requiring Preconcentration on Postirradiation Separations

The only elements of pollution concern which cannot normally be measured in sediments at natural background levels by INAA include $\mathrm{Ag}, \mathrm{Cd}, \mathrm{Cu}, \mathrm{Se}, \mathrm{Zn}$ and sometimes Hg. Radiochemical separation schemes are given below for these elements.

\section{Mercury Procedures}

One important point regardless of the type of postirradiation treatment is that $\mathrm{Hg}$ may be lost in drying the sediments--either by freeze drying or oven drying. Preferably, the Hg analysis should be made on the wet sediment, and the wet-dry weight ratio determined on a separate aliquot of the sediment.

Bothner and Piper (1972 unpublished data) have used nondestructive INAA to determine $\mathrm{Hg}$ levels of $0.5-17 \mathrm{ppm}$ in Bellingham Bay sediments, based on measuring the 279 $\mathrm{KeV} 20{ }^{3} \mathrm{Hg}$ gamma ray. However, most sediments will have $\mathrm{Hg}$ levels at or below the lower limit of detection by the INAA $203 \mathrm{Hg}$ method. Increased sensitivity is achieved by counting the $77 \mathrm{KeV}$ gamma rays from $197 \mathrm{Hg}$. However, because of the relatively high concentrations of ${ }^{24} \mathrm{Na}$ activity produced by irradiating marine sediments, the $197 \mathrm{Hg}$ must be chemically separated following the irradiation.

The main problem of postirradiation separations of $\mathrm{Hg}$ from neutron activated sediments is the dissolution of the samples. Ehmann and Lovering (1967) and Landstrom, et al (1969), point out that fusion of the sediments with $\mathrm{Na}_{2} \mathrm{O}_{2}$ or $\mathrm{Na}_{2} \mathrm{CO}_{3}$ is to be avoided, because of loss of $\mathrm{Hg}$ before equilibration with the carrier is achieved. The most recommended digestion procedure is with $\mathrm{HNO}_{3}^{-}$ $\mathrm{H}_{2} \mathrm{SO}_{4}$ in a Bethge apparatus or similar glass container, closed to prevent loss of $\mathrm{Hg}$. However, this method will not dissolve siliceous sediments and digestion with $\mathrm{HF}$ must be performed in addition to acid leaching; care 
being taken not to volatize Hg during the process.

Following the digestion there is no uniform procedure for the Hg separation but (Ehmann and Lovering (1967), Kennedy, et al (1971), and Landstrom, et al (1969), use a key ion exchange step, taking advantage of the strong affinity of Dowex 1 or 2 for chloro-complexes of $\mathrm{Hg}$ to bind $\mathrm{Hg}$ to the resin while eluting most interfering isotopes. The Hg was subsequently eluted and precipitated as HgS for counting (Ehmann and Lovering, 1967), or electroplated onto $\mathrm{Au}$ or Pt foils, Pillay, et al (1971), Landstrom, et al (1969), and Ljunggren, et al (1970).

An extremely useful summary of extraction, coprecipitation and ion exchange behavior of $\mathrm{Hg}$ in different acid solutions is in the reference: Roesmer, I., "Radiochemistry of Mercury" NAS-NS-3026 (Rev.) 1970.

Cadmium Separations

Once the sediment sample is dissolved by appropriate acid digestion, the general $c d$ separation procedures outlined in the section of analysis of marine organisms can be used.

Landstrom, et al (1969), Morrison, et al (1969) and Peterson, et al (1969) have outlined sequential group chemical separations schemes for measuring a large number of elements, including $C d$, in geological material by NAA. The methods of Morrison, et al, and Peterson, et al, are the same: After digestion of the sample by $\mathrm{H}_{2} \mathrm{SO}_{4}-\mathrm{HF}$ digestions the residue is dissolved in $8 \mathrm{~N} \mathrm{HCl}$ and passed through a column of hydrated antimony pentoxide (HAP) to remove ${ }^{24} \mathrm{Na}$. The effluent (and $8 \mathrm{~N} \mathrm{HCl}$ rinse) is passed through a column of Dowex $1 \times 8$ añion exchange resin which is then washed with $8 \mathrm{~N} \mathrm{HCl}$. The resin, rnntaini.ng sorbed radiocadmium and radionuclides of $\mathrm{Zn}, \mathrm{Sb}, \mathrm{Re}, \mathrm{Ir}$ and $\mathrm{Au}$ is counted directly on a Ge(Li) detector to measure $115 \mathrm{Cd}(54 \mathrm{hr})$.

Landstrom, et al (1969), treats the irradiated sediment with $\mathrm{H}_{2} \mathrm{SO}_{4}-\mathrm{HBr}$ to distill off the volatile bromides of $\mathrm{Hg}, \mathrm{Sn}, \mathrm{Sb}, \mathrm{As}$ and Se. The distillate is then digested with $\mathrm{HF}$ to complete the dissolution of siliceous material, and the residue is finally dissolved in $\mathrm{HCl}$ and passed through two columns of Dowex 2 anion exchange resins in the sulfate and hydroxide forms under various acid concentrations. The $c d$ is subsequently sorbed onto a column of Dowex 2 anion exchange resin in the sulfate form for counting of the ${ }^{11{ }^{5} \mathrm{Cd}}$ by gamma-ray spectrometry.

Copper and Silver separations

After dissolution of the neutron irradiated sediment by appropriate acid digestion the $\mathrm{Cu}$ and $\mathrm{Ag}$ can be separated 
by the procedures outlined in the sections on analyses of marine organisms and natural waters.

\section{Selenium Separations}

Case, et al (1969), described a group chemical separation method for determining $S e$ in geological material by NAA. The irradiated sample is dissolved by $\mathrm{H}_{2} \mathrm{SO}_{4}-$ $\mathrm{HF}$ digestion in the presence of carriers and made $6 \mathrm{~N}$ in $\mathrm{HCl}$ and $18 \mathrm{~N}$ in $\mathrm{H}_{2} \mathrm{SO}_{4}$. The Se is distilled by dropwise addition of $\mathrm{HBr}$ at $220^{\circ} \mathrm{C}$, using $\mathrm{N}_{2}$ carrier gas. The distilled Se is precipitated as the sulfide, which is then dissolved in $\mathrm{HCl}_{-} \mathrm{HNO}_{3}$ and counted by gamma-ray spectrometry to measure ${ }^{75} \mathrm{Se}$. If further radiochemical purity is required, the procedures given in the sections on natural water analyses could be employed.

Akaiwa (1966), Greenland (1967) and Kiesl (1969) have reported radiochemical separation schemes for measuring Se in meteorites and Wiersma and Lee (1971) and Chau and Riley (1965) described nonradioactive determinations of $\mathrm{Se}$ in fresh water and marine sediments. Any of the procedures could be readily adapted to the measurement of $\mathrm{Se}$ in marine sediments by NAA.

\section{Zinc Procedures}

zinc cannot routinely be measured in marine sediments, because the $1115 \mathrm{KeV}$ gamma-ray from its neutron activation product ${ }^{65} \mathrm{zn}$ is swamped by the high concentrations of $46 \mathrm{Sc}$, which has a major gamma ray of $1120 \mathrm{KeV}$. Therefore, to measure $65 \mathrm{zn}$ in neutron activated sediments, it needs only to be separated from ${ }^{46} \mathrm{Sc}$. The sequential separation schemes developed by Morrison, et al (1969) and Peterson, et al (1969), can be used for this purpose. The procedure is exactly the same as that described earlier for measuring $C d$ in sediments.

\section{E. Atmospheric Particulates}

1. Instrumental Analysis

The contamination of the oceans by deposition of anthropogenic aerosols from polluted atmospheres is of real concern (see Duce, et al, 1972 and Robertson, et al 1972, for examples). It is essential that the atmospheric con.. centrations of metal pollutants be monitored especially at coastal locations so that estimates of the air-to-sea transfer rates of these aerosols can be made. For the multielement analysis of atmospheric particulates collected on filter media, no analytical method can match INAA for sensitivity and selectivity. Up to 33 elements 
can be measured in urban air by this nondestructive technique of selecting optimum neutron irradiation and counting times for the detection and measurement of neutron activation products ranging in half-life from 2.3 minutes to 5.3 years (Dams, et al 1970; Dudey, et al 1969; Gordon, 1971; Tuttle, 1969; Zoller and Gordon, 1970).

The collection and preparation of samples for INAA is relatively simple. Atmospheric particulate matter is collected on suitable tared filter media (Whatman 41, Millipore, Nuclepore, etc.) by pumping 50 to several thousand cubic meters of air through the filters. Air volumes are measured with recording flow meters or integrating flow meters. After collection, the filters are reweighed to determine the total weight of solids collected, and the filter or a known fraction of it is removed and encapsulated in a polyethylene irradiation vial. The filters and appropriate standards are then neutron activated for predetermined time intervals for the measurement of short- and long-lived neutron activation products.

A typical procedure for the analysis of elements forming short-lived activation products is to irradiate the filter sample for 5 minutes in a rabbit facility at a thermal neutron flux of about 1 to $50 \times 1012 \mathrm{n} / \mathrm{cm}^{2} / \mathrm{sec}$, wait 2 to 10 minutes after the irradiation and then count the sample for 5 to 10 minutes on a $\mathrm{Ge}(\mathrm{Li})$ diode detector. For the measurement of elements forming intermediate and long-lived radionuclides, the same sample or a portion of the same filter, plus elemental standards, are irradiated for 5 to 8 hours at a thermal neutron flux of 1 to $50 \mathrm{x}$ $10^{12} \mathrm{n} / \mathrm{cm}^{2} / \mathrm{sec}$, and the samples and standards are then transferred into new counting containers and counted on a $\mathrm{Ge}(\mathrm{Li})$ diode detector for about 10 to 30 minutes when 1 to 3 days out of the reactor, and for about 60 to 200 minutes when 10 to 30 days out of the reactor. 
The typical gamma-ray spectra which are obtained under these conditions are illustrated in Figure 11. In this particular aerosol sample collected in Cleveland, Ohio, it is possible to measure from the short count the trace elements $\mathrm{Al}, \mathrm{Mg}, \mathrm{Ti}, \mathrm{V}, \mathrm{Cu}, \mathrm{Cl}, \mathrm{Ba}, \mathrm{Mn}$ and $\mathrm{Br}$. From the intermediate count it is possible to measure $\mathrm{Na}, \mathrm{K}$, As, $\mathrm{Br}, \mathrm{Sb}, \mathrm{Sm}, \mathrm{La}, \mathrm{U}$ and $\mathrm{Cd}$; and from the long count the elements $\mathrm{Cu}, \mathrm{Fe}, \mathrm{Co}, \mathrm{Zn}, \mathrm{Se}, \mathrm{Sb}, \mathrm{Cr}, \mathrm{Cs}, \mathrm{Ce}, \mathrm{Eu}, \mathrm{Yb}, \mathrm{Hf}$, $\mathrm{Hg}$ and $\mathrm{Th}$. The actual concentrations of these elements in this particular filter are given in Table 6. This filter contained an usually high concentration of $\mathrm{Sb}$, which was obviously released from some particular industry located in the sampling vicinity.

The detection sensitivities achieved by INAA for multielement analysis of aerosols are not fixed values, but are dependent to a large degree upon the composition of the sample. For example, the relatively high concentration of $\mathrm{Sb}$ on the Cleveland air filter shown in Figure 11 limited the sensitivity of those elements forming neutron activation products with gamma-rays of lower energy than the main $124 \mathrm{Sb}$ gamma rays at 603 and $1691 \mathrm{KeV}$. The Compton scattering from these and other. ${ }^{24} \mathrm{Sb}$ gamma rays produced a relatively high "background" for the measurement of other gamma rays of lower energies. Nevertheless, estimates of the detection sensitivities of the elements which can be measured by INAA are useful and give one a feel for the excellent sensitivities which are obtainable by this technique.

An estimation of the minimum detectable concentrations of 37 elements in urban aerosols as measured by INAA is given in Table 7 . The sensitivities obtainable $\left(\mu \mathrm{g} / \mathrm{m}^{3}\right)$ in nonurban aerosols are even greater than those shown in Table 7, since larger volumes of cleaner air (lesser interelement interferences) can be sampled. The INAA method possesses the sensitivity to directly measure all of the metal pollutants of interest, except $\mathrm{Cd}, \mathrm{Pb}$, 
FIGURE 11

GAMMA-RAY SPECTRUM OF NEUTRON ACTIVATED CLEVELAND AIR FILTER

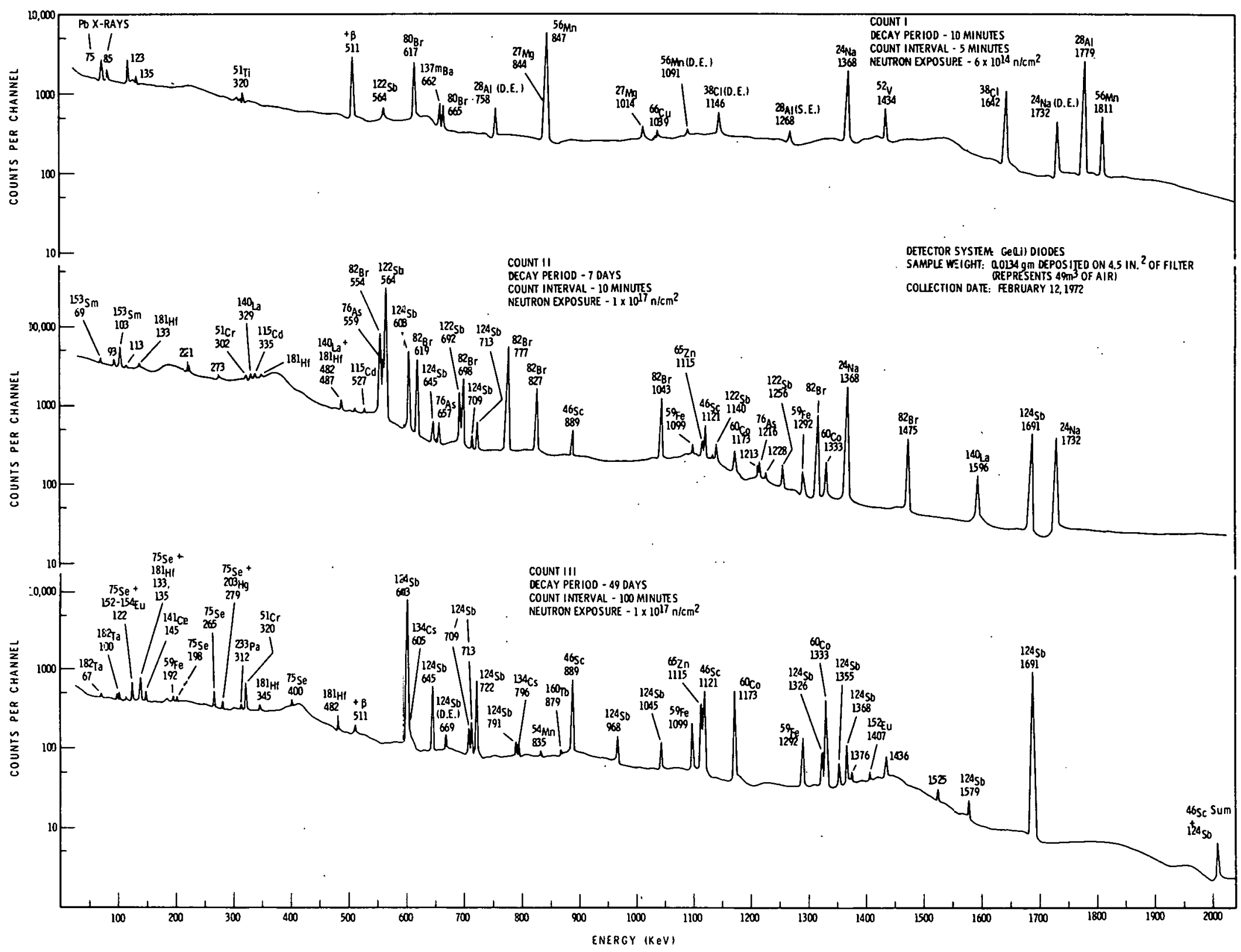


TABLE 6

ELEMENTAL CONCENTRATIONS IN CLEVELAND AIR FILTERS FEBRUARY 12,1972

\begin{tabular}{|c|c|c|}
\hline Element & $\mathrm{ng} / \mathrm{m}^{3} \mathrm{Air}$ & $\mu \mathrm{g} / \mathrm{gm}$ Particulate \\
\hline Al & 9890 & 36600 \\
\hline As & 316 & 1170 \\
\hline $\mathrm{Br}$ & 513 & 1900 \\
\hline $\mathrm{Cl}$ & 9450 & 34900 \\
\hline $\mathrm{Co}$ & 32.7 & .121 \\
\hline $\mathrm{Cr}$ & 96 & 360 \\
\hline Eu & 0.075 & 0.28 \\
\hline $\mathrm{Fe}$ & 9750 & 36100 \\
\hline $\mathrm{H} f$ & 1.61 & 5.96 \\
\hline $\mathrm{Hg}$ & $<0.03$ & $<0.1$ \\
\hline $\mathrm{La}$ & 7.2 & 27 \\
\hline $\mathrm{Mg}$ & 2190 & 8100 \\
\hline $\mathrm{Mn}$ & 277 & 1030 \\
\hline $\mathrm{Na}$ & 10460 & 38700 \\
\hline $\mathrm{Sb}$ & 503 & 1860 \\
\hline $\mathrm{Sc}$ & 2.41 & 8.92 \\
\hline $\mathrm{Se}$ & 27.4 & 101 \\
\hline $\mathrm{Sm}$ & 1. 20 & 4.44 \\
\hline $\mathrm{Ta}$ & 0.66 & 2.4 \\
\hline $\mathrm{Tb}$ & 0.21 & 0.78 \\
\hline Th & 0.72 & 2.7 \\
\hline $\mathrm{Ti}$ & 630 & 2330 \\
\hline V & 17.8 & 65.9 \\
\hline $\mathrm{Zn}$ & 1040 & 3850 \\
\hline
\end{tabular}


TABLE 7

SINSITIVITIES FOR DETERMINATION OF TRACE ELEMENTS IN AEROSOLS BY INAA (After Dams, et al, 1970)

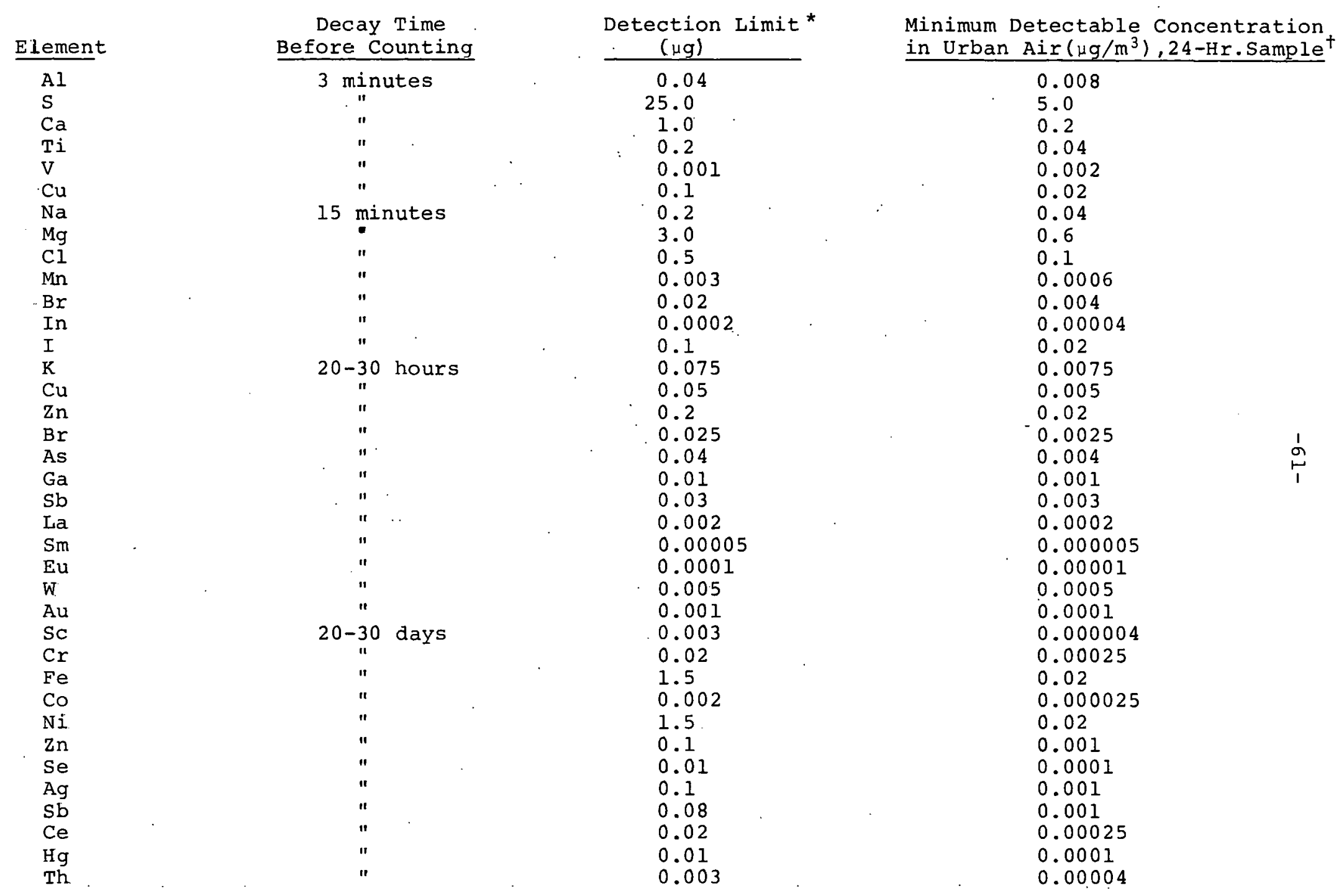

Air filters ( $20 \times 25 \mathrm{~cm}$, or aliquots thereof) neutron irradiated at optimum intervals ranging from $5 \mathrm{~min}$. to $5 \mathrm{~h}=\mathrm{s}$ at fluxes of $2-15 \times 10^{12} \mathrm{n} / \mathrm{cm}^{2} / \mathrm{sec}$; Counted for 7 to $70 \mathrm{~min}$ at optimum intervals ranging from $3 \mathrm{~min}$ to 20-30 days after the irradiation; $30 \mathrm{cc}$ Ge(Li) detector.

$+24 \mathrm{hr}$ sampling period at air sampling rate of $12 \mathrm{liters} / \mathrm{min}-\mathrm{cm}^{2}$. 
and sometimes $\mathrm{Ag}, \mathrm{Cu}$ and $\mathrm{Hg}$. Cadmium, $\mathrm{Cu}, \mathrm{Ag}$ and $\mathrm{Hg}$ can be measured by neutron activation followed by radiochemical separation of their activation products. Although $\mathrm{Pb}$ and $\mathrm{Sn}$ are insensitive to neutron activation analysis, it is worth pointing out that another nuclear method of analysis, X-ray fluorescence spectrometry, is a convenient method for the nondestructive analysis of $\mathrm{Pb}$ in aerosol samples.

2. Analysis of Elements Requiring Preconcentration or Postirradiation Separations

Occassionally, $\mathrm{Cd}, \mathrm{Cu}, \mathrm{Ag}$ and $\mathrm{Hg}$ are present on air filters in concentrations too low to measure by INAA and radiochemical separations of the neutron activated filters are necessary to separate interfering radionuclides. Since the particulate material collected on aerosol filters resembles geological and/or biological matrices, the radiochemical separations for these elements from irradiated air filters is the same as those described for geological and/or biological materials. The filters and collected aerosols are dissolved by digestion in $\mathrm{H}_{2} \mathrm{SO}_{4}-\mathrm{HF}$ or $\mathrm{HNO}_{3}-\mathrm{HF}$. Once the samples are in solution, the previously described radiochemical separations for the elements of interest may be performed.

\section{ACKNOWLEDGMENT}

The authors wish to acknowledge the capable assistance of T. M. Tanner and L. A. Rancitelli of Battelle, Pacific Northwest Laboratory for providing helpful information and data for the preparation of the sections dealing with fresh water, airborne particulate and biological tissue analyses. 
REFERENCES

Akaiwa, H., Abundances of Selenium, Tellurium, and Indium in Meteorites, J. Geophys. Res., 71:1919-1923 (1966).

Anonymous. Nuclear Technigues in Environmental pollution, Proceeding of a Symposium, Salzburg, Austria, October 26-30, 1970, International Atomic Energy Agency, Vienna, 1971.

Barbier, M., Induced Radioactivity, North-Holland Publishing Company, Amsterdam, 1969.

Bate, L. C., Loss of Mercury from Containers in Neutron Activation Analysis, Radiochem. Radioanalyt. Letters 6: 139-144 (1971).

Battistone, E. L. and R. Lofberg, Simplified Untramicro-determination of Copper in Biological Specimens by Neutron Activation Analysis, Clin. Chim. Acta., 30:429-438 (1970).

Bertolini, G. and A. Coche, Semiconductor Detectors, Wiley Interscience, John Wiley and Sons, Inc., New York, 1968 .

Bird, E. D., et al., Neutron Activation Analysis of Brain for Copper and Manganese, in Modern Trends in Activation Analysis, National Bureau of Standards Special Publication 312, Vol. I, National Bureau of Standards, Washington, D.C., 1969, pp. 138-141.

Bowen, H. J. M., The Determination of Chromium in Biological Material by Radioactivation, Analyst, 89: 658-661 (1964).

Bowen, H. J. M., The Determination of Antimony, Cadmium, Cerium, Indium, and Silver in Biological Material by Radioactivation, Analyst, 92: 118-123 (1967).

Brown, W. L., et al, Eds. Semiconductor Nuclear-Particle Detectors and Circuits, Publication 1593, National Academy of Sciences, Washington, D. C., 1969 .

Brune, D. and K. Jirlow, Determination of Mercury in Aqueous Samples by Means of Neutron Activation Analysis with Account of Flux Disturbances, Radioanal. Chim., 8: 16I-164 (1967).

Brune, D. and O. Landstrom, Freezing Technique in Neutron Activation Analysis, Radiochim. Acta., 5: 228-230 (1966).

Brunfelt, A. O. and Steinnes, E., Instrumental Neutron Activation Analysis of "Standard Rocks," Geochim. Cosmochim. Acta., 30: 921$928(1966)$.

Camp, D. C., Applications and Optimization of the Lithium-Drifted Germanium Detector System," UCRL-50156, Lawrence Radiation Laboratory, University of California, Livermorc, Califorinia, March 1, 1967.

Case, D. R., Simultaneous Measurement of Seventeen Trace Elements in Eight Geochemical Standards: A Novel Adaptation of Neutron Activation Analysis, in Modern Trends in Activation Analysis. National Bureau of Standards Special publication 312, Vol. I, National Bureau of standards Washington, D. C., June, 1969, pp. 409-412. 
Chau, Y. K. and J. P. Riley, The Determination of Selenium in Seawater, Silicates and Marine Organisms, Anal. Chim. Acta, $33: 36-49$ (1965).

Chuecas, L. and J. P. Riley, The Spectrophotometric Determination of Chromium in Seawater, Anal. Chim. Acta, 35: 240 (1966).

Cooper, J. A., Applied Ge( $\mathrm{Li})$ Gamma-Ray Spectroscopy, in Contemporary Activation Analysis, V. A. Ryan, Ed., Marcel Dekker, Inc. New York, 1973.

Cooper, J. A. and R. W. Perkins, A Versatile Ge(Li)-NaI(TI) Coincidence-Anticoincidence Gamma-Ray Spectrometer for Environmental and Biological Problems, Nucl. Instr. \& Methods, 99: 125-146 (1972).

Dams, R., et al., Nondestructive Neutron Activation Analysis of Air Pollution Particulates, Anal. Chem. 42: 861-867 (1970).

Das, H. A. and H. H. de Vries, Trace-Determination of Cadmium by Neutron Activation. Application to Air-Borne Particulates, Hair and Foodstuffs, RCN-136, Petten, February, 1971.

Dearnaley, G. and D. C. Northrop, Semiconductor Counters for Nuclear Radiations, John Wiley and Sons, Inc., New York, 1966.

DeVoe, J. R. The Radiochemistry of Cadmium, NAS-NS-3001, USAEC, Office of Technical Services, Dept., of Commerce, Washington, D.C., January, 1960 .

DeVoe, J. R. and P. D. Lafleur, Eds., Modern Trends in Activation Analysis, National Bureau of Standards Special Publication 312, Vols. I and II, National Bureau of Standards, Washington, D. C., June 1969.

Duce, R. A., et al, Enrichment of Heavy Metals and Organic Compounds in the Surface Microlayer of Narragansett Bay, Rhode Island, Science, 176 : $161-163$ (1972).

Dudey, N. D., L. E. Ross and V. E. Noskin, Application of Activation. Analysis and $\mathrm{Ge}(\mathrm{Li})$ Detection Techniques for the Determination of stable Elements in Marine Aerosols, in Modern Trends in Activation Analysis, National Bureau of Standards Special Publication 312, Vol. I, National Bureau of Stds., Washington, D.C., 1969, pp. 55-61.

Edgington, D. N. and H. F. Lucas, Jr., A Semi-Automatic Method of Neutron Activation Analysis With Application to Environmental Studies, in Nuclear Techniques in Environ. Pollution, October 26-30, 1970, Salzburg, Austria, International Atomic Energy Agency, Vienna, 1971.

Edgington; D. N. and H. F. Lucas, Jr., A System for the Neutron Activation Analysis of Trace Elements in Samples of Biological and Environmental Interest, J. Radioanal. Chem., 5: 233-250 (1970).

Ehmann, W. D. and J. F. Lovering, The Abundance of Mercury in Meteorites and Rocks by Neutron Activation Analysis, Geochim. Cosmochim. Acta, 31: 357-376 (1967).

Filby, R. H., W. A. Haller and K. R. Shah, Determination of 32 Elements in Rocks by Neutron Activation Analysis and High Resolution Gamma-Ray Spectroscopy, J. Radioanal. Chem., 5: 277-290 (1970). 
Flanagan, F. J., U. S. Geological Survey Standards-II. First Compilation of Data for the New U.S.G.S. Rocks, Geochim. Cosmochim. Acta, 33: 81-120 (1969).

Fleischer, M., Summary of New Data on Rock Samples G-1 and W-1, Geochim. Cosmochim. Acta, 29: 1263-1284 (1965).

Fukai, R. Valency State of Chromium in Seawater, Nature 213:901 (1967).

Girardi, F. and E. Sabbioni, Selective Removal of Radio-Sodium from Neutron-Activated Materials by Retention of Hydrated Antimony Pentoxide, J. Radioanal. Chem., 1: 169-178 (1968).

Gordon, G. E., Instrumental Activation Analysis of Atmospheric Pollutants and Pollution Source Materials, in International symposium on Identification and Measurement of Environmental Pollutants, Ottawa, Ontario, Canada, June 14-17, 1971.

Gordon, G. E., et al, Instrumental Activation Analysis of Standard Rocks with High Resolution Gamma-Ray Detectors, Geochim. Cosmochim. Acta, 32: 369-396 (1968).

Goya, H. A. and.M. G. Lai, Adsorption of Trace Elements from Seawater by Chelex-100, USNRDL-TR-67-129, U. S. Naval Radiological Defense Laboratory, san Francisco, California, September 1967.

Greenland, L., The Abundances of Selenium, Tellurium, Silver, Palladium, Cadmium and $\mathrm{Zinc}$ in Chondritic Meteorites, Geochim. Cosmochim. Acta, 31: 849-860 (1967):

Guinn, V. P. and H. R. Lukens, Jr., Nuclear Methods, in Trace Analysis - Physical Methods, G. H. Morrison, Ed., Interscience Publishers, New York, 1965, pp. 307-336.

Hahn, K. J., D. J. Tuma and J. L. Sullivan, Rapid and Simple Continuous Radiochemical Separation of Copper, Magnesium, Zinc and Manganese in Biological Materials, Anal. Chem. 40: 974-976 (1968).

Haller, W. A., et al, The Instrumental Determination of Fifteen Elements in Plant Tissue by Neutron Activation Analysis, in Modern Trends in Activation Analysis, National Bureau of Standards $\overline{\text { Special }}$ Publication 312, National Bureau of Stds., Washington, D.C., June 1969, pp. 177-183.

Heath, R. L., Gamma-Ray Spectrometry and Automated Data Systems for Activation Analysis, in Modern Trends in Activation Analysis, National Bureau of Standards special Publication 312, Vol. II, pp. 959-1031, National Bureau of Stds., Washington, D. C., June 1969.

Hollander, J. M., The Impact of Semiconductor Detectors on Gamma-Ray and Electron Spectrography, Nucl. Instr. \& Methods 43: 65-109 (1966).

Joyner, T., et al, Preconcentration for Trace rnalysis of Sea Waters, Environ. Sci. Tech., 1: 417-424 (1967).

Keil, G. and H. Bernt, Eds., Semiconductor Detectors for Nuclear Radiation, Nucl. Instr.\& Methods 101: 1-172 (1972). 
Kennedy, et al, Environmental Geology Note \#44, Mercury in Lake Michigan Sediments, 1971.

Kharkar, D. P., K. K. Turekian and K. K. Bertine, Stream Supply of Dissolved Silver, Molybdenum, Antimony, Selenium, Chromium, Cobalt, Rubidium, and Cesium to the Oceans, Geochim. Cosmochim. Acta, 32 : 285-298 (1968).

Kiesl, W., Determination of Trace Elements in Meteorites by Neutron Activation Analysis, in Modern Trends in Activation Analysis, National Bureau of Standards Special Publication 312, Vol. I, National Bureau of Stds., Washington, D. C., June 1969, pp. 302-307.

Kim, C. K. and J. Silverman, Determination of Mercury in wheat and Tobacco Leaf by Neutron Activation Using Mercury-197 and a Simple Exchange Separation, Anal. Chem. 37: 1616-1617 (1965).

Kruger, P., Principles of Activation Analysis, Wiley-Interscience, $\mathrm{J}$. Wiley and Sons, New York, 1971 .

Lai, M. G. and Weiss, H. V. (1962) Cocrystallization of Ultramicro Quantities of Elements with Thionalid, Anal. Chem. 34: 1012-1015.

Landstrom, O., K. Samsahl and C. G. Wenner, An Investigation of Trace Elements in Marine and Lacustrine Deposits by Means of a Neutron Activation Method, in Modern Trends in Activation Analysis, National Bureau of Standards special publication 312, Vol. I, National Bureau of Stds., Washington, D.C. June 1969, pp. 353-366.

Landstrom, $0 .$, and C. G. Wenner, Neutron-Activation of Natural Water Applied to Hydrology, AE-204, December 1965.

Lenihan, J. M. and S. J. Thompson, Eds., Advances in Activation Analysis, Academic Press, New York, 1969.

Livingston, H. D., H. Smith and N. Stofanovic, Simultaneous Estimation of Copper, Zinc, Cadmium and Mercury in Biological Material by Neutron Activation Analysis, Talanta, 14: 505-513 (1967).

Lieberman, K. W., and H. H. Kramer, Cadmium Determination of Biological Tissue by Neutron Activation Analysis, Anal. Chem. 42: 266-267 (1970).

Ljunggren, K., et al, Activation Analysis of Mercury and Other Environmental Pollutants in Water and Aquatic Ecosystems, in Nuclear Techniques in Environmental Sciences, October 26-30, 1970, salzburg, Austria, International Atumic Energy Agency, Vienna, 1971.

Lutz, G. L., et al, Eds, Activation Analysis: A Bibliography, Technical Note 467, Parts 1 and 2, National Bureau of Standards, Washington, D.C., May 1971.

Meloni, S., A. Brandone and V. Maxio, Chromium Separation by Inorganic Exchangers in Activation Analysis of Biological Materials, in Modern Trends in Activation Analysis, National Bureau of standards Special Publication 31.2, Vol. I, National Bureau of Stds., Washington, D. C., June 1969 , pp. 642-645. 
Merlini, M., et al., Trends in the Concentration of Heavy Metals in Organisms of a Mesotrophic Lake as Determined by Activation Analysis, in Nuclear Techniques in Environmental Sciences, October 26-30, 1970, Salzburg, Austria, International Atomic Energy Agency, Vienna, 1971.

Minczewski, J., Preconcentration in Trace Analysis, in Trace Characterization-Chemical and Physical, W. W. Meinke and B. F. Scribner, Eds., National Bureau of Standards Monograph 100, National Bureau of Stds., Washington, D. C. 1967, pp. 385-414.

Mizuike, A., Separation and Preconcentrations, in Trace AnalysisPhysical Methods, G. H. Morrison, Ed., Interscience Publishers, New York, 1965, pp. 103-153.

Morris, D. F. C. and R. A. Killick, The Determination of Mercury in Rocks by Neutron Activation Analysis, Talanta, 11: 781-788 (1964).

Morrison, G. H., et al, Multielement Neutron Activation Analysis of Rock Using Chemical Group Separations and High Resolution GammaSpectrometry, Anal. Chem., 41: 1633-1637 (1969).

Morrison, G. H. and N. H. Potter, Multielement Neutron Activation Analysis of Biological Material Using Chemical Group Separations and High Resolution Gamma Spectrometry, Anal. Chem., 44: 839-842 $(1972)$.

O'Kelley, G. D., Ed, Applications of Computers to Nuclear and Radiochemistry, Gatlinburg Symposium, October:1962, NAS-NS-3107 (1962).

Perkins, R.W., and D. E. Robertson, Selective and Sensitivie Analysis of Activation Products by Multidimensional Gamma-ray Spectrometry, Proceedings of the International Conference: Modern Trends in Activation Analysis, College Station, Texas, April 19-22, CONF-650405, 48-57, Division of Technical Information Extension, USĀEC, 1965.

Peterson, S. F., A. Travesi and G. H. Morrison, Rapid Group Separation Method for Neutron Activation Analysis of Geological Materials, in Modern Trends in Activation Analysis, National Bureau of Standards Special Publication 312, Vol. I, National Bureau of Stds. , Washington, D. C. June 1969, pp.624-633.

Pijck, I., Radiochemistry of Chromium, NAS-NS-3007 (Rev. 1964), USAEC, Washington, D. C., 1964.

Pillay; K. K. S. , et al, Determination of Mercury in Biological and Environmental Samples by Neutron Activation Analysis, Anal. Chem., 43: $1419-1425$ (1971).

Portman, J.E. and J. P. Riley, Determination of Arsenic in Seawater, Marine Plants and Silicate and Carbonate Sediments, Anal. Chim. Acta, 31: 509-519 (1964).

Rakevic, M. , Activation Analysis, CRC Press, Cleveland, Ohio, 1970.

Rancitelli, L. A., J. A. Cooper and R. W. Perkins, The Multielement Analysis of Biological Material by Neutron Activation and Direct Instrumental Techniques, in Modern Trends in Activation Analysis, National Bureau of Standards Special Publication 312, Vol. I, National Bureau of Stds., Washington, D.C., June 1969, pp. 101-109. 
Ray, B. J. and D. L. Johnson, A Method for the Neutron Activation Analysis of Arsenic in Natural Waters, to be published in Anal. Chim. Acta, 1972 .

Riley, J. P. and D. Taylor, Chelating Resins for the Concentration of Trace Elements from Sea Water and Their Analytical Use in Conjunction with Atomic Absorption Spectrophotometry, Anal. Chim. Acta, 40: 479485 (1968).

Robertson, D. E., Role of Contamination in Trace Element Analysis of Seawater, Anal. Chem, 40: 1067-1072 (1968).

Robertson, D.E., Contamination Problems in Trace Element Analysis and Ultrapurification, in Ultrapurity-Methods and Techniques, M. Zief and R. Speights, Eds., Marcel Dekker, Inc., New York, 1972.

Robertson, D. E., L. A. Rancitelii and R. W. Perkins, Multielement Analysis of Seawater, Marine Organisms and Sediments by Neutron Activation without Chemical Separations, Proceedings of International Symposium on the Application of Neutron Activation Analysis in Oceanography, Institut Royal de Sciences Naturelles de Belgique, Bruxelles, Belgique, June 1968.

Robertson, D. E., et al, Battelle-Northwest. Contribution to the IDOE Base-Line Study, in Baseline studies of pollutants in the Marine Environment--Background Papers for a Workshop Sponsored by the National Science Foundation's Office for the International Decade of Ocean Exploration, Brookhaven National Laboratory, May 24-26, 1972, pp. $231-275$.

Rona, E., et al, Activation Analysis of Manganese and Zinc in Sea Water, Limnol. Oceanog., 7: 201-206 (1962).

Ryan, V. A. , Ed, Contemporary Activation Analysis, Marcel Dekker, Inc..., New York, (to be published in 1973).

Salmon, L. and M. G. Creevy, An On-Line Computer System for Instrumental Activation Analysis of Air, Water and Soil, in Nuclear Techniques in Environmental Pollution, Salzburg, Austria, October 26-30, 1970, pp. 47-59.

Samsahl, K., Radiochemical Method for Determination of Arsenic, Bromine, Mercury, Antimony and Selenium in Neutron Activated Biological Material, Anal. Chem., 39: 1480-1485 (1967).

Samsahl, K., P. O. Wester and O. Landstrom, An Automatic Group Separation System for Simultaneous Determination of a Great Number of Elements in Biological Material - Recovery and Reproducibility studies, Anal. Chem., 40: 181-187 (1968).

Schutz, D. F. and K. K. Turekian, The Distribution of Cobalt, Nickel and Silver in Ocean Water Profiles Around Pacific Antarctica, J. Geophy. Res., 70:5519-5528 (J.965a).

Schutz, D. F. and Turekian, K. K., Geographical and Vertical Distribution of Several Trace Elements in Sea Water Using Neutron Activation Analysis, Geochim. Cosmochim. Acta, 29: 259-313 (1965b). 
Slowey, J. F. and D. W. Hood. Copper, Manganese and Zinc Concentrations in Gulf of Mexico Waters, Geochim. Cosmochim, Acta, 35: 121-138 (1971).

Smales, A. A. Radioactivity Techniques in Trace Characterization. in Trace Characterization, W. W. Meinke and B. F. Scribner, Eds, National Bureau of Standards Monograph 100, National Bureau of Stds., Washington, D. C. April 28, 1967, pp. 307-336.

Stanford, H. M. The Concentration and oxidation state of Chromium in Sea Water, Ecological Studies of Radioactivity in the Columbia River Estuary and Adjacent Pacific Ocean, Progress Rpt. July 1, 1970 through June 30, 1971, Oregon State Univ., Dept., of Oceanography, July 1971, 17.

Tanner, T. M., L. A. Rancitelli and W. A. Haller, Multielement Analysis of Natural Waters by Neutron Activation, Group Chemical Separations and Gamma-Ray Spectrometric Techniques, Water, Air and Soil pollution, $1: 132-143$ (1972).

Thatcher, L. L. and J. O. Johnson, A Comprehensive Program in Neutron Activation Analysis in Water Quality, in Nuclear Techniques in Environmental Sciences, October 26-30, 1970, Salizburg, Austria, IAEA, Vienna, 1971.

Thiers, R. E., in Methods of Biochemical Analysis, D. Glick, Ed, Vol. 5, Interscience, New York, 1957, pp. 274-309.

Thiers, R. E., in Trace Analysis, J. H. Yoe and H. J. Koch, Jr., Eds, Wiley, New York, 1957, pp. 637-666.

Turekian, K. K., The Ocean, Streams and Atmosphere: Chapter 10 in Handbook of. Geochemistry, K. H. Wederpohl, et al., Eds, SpringerVerlag, Berlin, 1969.

Tuttle, R. E. , et al, Neutron Activation Analysis of Trace Elements in Airborne Particulates in Nuclear Techniques in Environmental

Pollution, October 26-30, 1970, Salzburg, Austria, IAEA, Vienna, 1971.

U. S. Dept. of Health, Education and Welfare, Public Health Service Publication No. 956, U. S. Government, Revised, 1962 .

Weiss, H. V., M. Koide and E. D. Goldberg, Selenium and Sulfur in a Greenland Ice Sheet: Relation to Fossil Fuel Combustion, Science 172: 261-263 (1971).

Weiss, H. V. and T. E. Crozier, Determination of Mercury in Seawater by Radioactivation, Anal. Chim. Acta, 58: 231-233 (1972).

Wiersma, J. H. and G. F. Lee, Selenium in Lake Sediments - Analytical Proredure and Preliminary Results, Environ. Eci. Tech. 5: 1203-1206 (1971).

Wogman, N. A. , D. E. Robertson and R. W. Perkins. A Large Well Crystal with Anticoincidence Shielding, Health Phys. 13: 7670773 (1967).

Zoller, W. H. and G. E. Gorden, Instrumental Neutron Activation Analysis of Atmospheric Pollutants Utilizing Ge(Li) Gamma-Ray Detectors, Anal. Chem. 42: 257-265 (1970). 


\section{APPEND IX}

PERTINENT NUCLEAR OATA RELATING TO THE MEASUREMENT OF THE TRACE METALS

IN MARINE ENVIRONMENT SAMPLES BY INSTRUMENTAL AND NON.INSTRUMENTAL NEUTRON ACTIVATION ANALYSIS

TARGET ISOTOPIC THERMAL NEUTRON BEST GAMMA-RAY NUMBER OF

\begin{tabular}{|c|c|c|c|c|c|c|c|c|c|}
\hline ELEMENI & $\begin{array}{l}\text { TARGET } \\
\text { ISOTOPE } \\
\end{array}$ & $\begin{array}{c}\text { ISOTOPIC } \\
\text { ABUNDANCE, } \% \\
\end{array}$ & $\begin{array}{l}\text { PRODUCT } \\
\text { NUCLIDE } \\
\end{array}$ & $\begin{array}{l}\text { HALF- } \\
\text { LIFE } \\
\end{array}$ & $\begin{array}{l}\text { THERMAL NEUTRON } \\
\text { CROSS SECTION } \\
\text { (BARNS) } \\
\end{array}$ & $\begin{array}{l}\text { BEST GAMMA-RAY } \\
\text { FOR MEASUREMENT } \\
\text { KeVI } \\
\end{array}$ & $\begin{array}{l}\text { NUMBER OF } \\
\text { GAMMA PER } \\
1000 \text { DECAYS } \\
\end{array}$ & $\begin{array}{l}\text { ASSOCIATEO GAMMA-RAYS } \\
\mathrm{KeV}\left(Y^{\prime} S / 1000 \text { DISINTEG. }\right.\end{array}$ & $\begin{array}{c}\text { POS SIBLE INTERFRRING } \\
\text { RADIONUCLIDES IN MEASUREMENT OF } \\
\text { BEST GAMMA-RAY (KEV) }\end{array}$ \\
\hline \multirow[t]{2}{*}{ Ag } & $\mathrm{Ag}-107$ & 51.82 & $\mathrm{Ag}-108$ & $24 m$ & 35 & 633 & 17 & $4334.51,614(26)$ & $N d-151(629), N d-149(630), D y-165(633)$ \\
\hline & $A g-109$ & 48.18 & $\mathrm{Ag}-110 \mathrm{~m}$ & 2600 & 3 & 657 & 900 & $764(230), 884(710), 937017), 1384(211)$ & As $-76(657)$ \\
\hline Al & $A \mid-27$ & 100 & Al -28 & $23 \mathrm{~m}$ & 0.23 & 1779 & 1000 & NONE & $N d-151(1776)$ \\
\hline As & As -75 & 100 & As -76 & $26.5 \mathrm{~h}$ & 4.5 & 559 & 440 & $657(66)$ & $\mathrm{Br}-82(554), \mathrm{Nd}-149(556), \mathrm{Eu}-152 \mathrm{~m}(562)$ \\
\hline Au & $A u-197$ & 100 & $A u-198$ & $64.8 \mathrm{~h}$ & $\$ 8$ & 411 & 960 & $676(9.7), 1088(1.94)$ & $E u-152(416), \mid r-192(417)$ \\
\hline \multirow[t]{2}{*}{$\mathrm{Ba}$} & Ba-130 & 0.101 & Ba-131 & $11: 60$ & 88 & 496 & 450 & $124(200), 216(190), 373(130)$ & $C d-115(492), R u-103(49)$ \\
\hline & $B a-138$ & 71.66 & $8 a-139$ & $83 m$ & 0.4 & 166 & 217 & 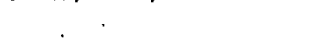 & $\begin{array}{l}\text { Th-233(163), Gd-161(165), Th-233(169), } \\
\text { Mg-27(170), Nd-151(171) }\end{array}$ \\
\hline $\mathrm{Br}$ & $\mathrm{Br}-81$ & 49.463 & $\operatorname{Er}-82$ & $35.5 \mathrm{~h}$ & 3.3 & 77 & 257 & $554(226), 619(133), 1044(90), 1317(87)$ & $w-187(772)$, As $-76(775)$, Eu-152(779) \\
\hline $\mathrm{Ce}$ & $\mathrm{Ce}-140$ & 85.48 & $C e-141$ & 3250 & 0.6 & 145 & 490 & NONE & $\begin{array}{l}\mathrm{Ce}-143(142), \mathrm{Fe}-59(142), \mathrm{Yb}-175(145) \\
\text { Eu-154(146), Eu-152(148), Je-131m(150) }\end{array}$ \\
\hline \multirow[t]{2}{*}{$\mathrm{Cd}$} & Cd-114 & 28.86 & $\mathrm{Cd}-115$ & 23d & 1.1 & 335 & 528 & $492(101), 528(264)$ & Te-131m(334), $\mathrm{Fe}-59(334), \mathrm{Tb}-160(337)$ \\
\hline & Cd-116 & 7.58 & Cd-117 & $25 \mathrm{~h}$ & 1.4 & 273 & 310 & $314(160), 345(180), 434(13)$ & $\mathrm{Br}-82(273)$ \\
\hline $\mathrm{Cl}$ & $\mathrm{Cl}-37$ & 24,471 & $\mathrm{Cl}-38$ & $37.3 \mathrm{~m}$ & 0.56 & 1642 & 380 & $2167440)$ & NONE \\
\hline Co & $\mathrm{C}_{0}-59$ & 100 & $\mathrm{C}_{0}-60$ & $5.24 y$ & 19 & 1332 & 1000 & $1173(1000)$ & NONE \\
\hline $\mathrm{Cr}$ & $\mathrm{Cr}-50$ & 4.31 & $\mathrm{Cr}-51$ & 27.80 & 17 & 320 & 90 & NONE & $\begin{array}{l}\text { Ir-192(317), Lu-177019), Nd-147019), } \\
\text { Os-193(321) Lu-177321) }\end{array}$ \\
\hline \multirow{3}{*}{$\begin{array}{l}\text { Cs } \\
\text { Cu }\end{array}$} & Cs -133 & 100 & Cs-134 & $2.1 y$ & 28 & 795 & 880 & $475(150), 569(140), 605(980)$ & Te-131m(794) \\
\hline & $\mathrm{Cu}-63$ & 69.09 & $\mathrm{Cu}-64$ & 12.91 & 4.5 & 511 & 380 & 134561 & ALL POSITRON EMITIERS \\
\hline & $\mathrm{Cu}-65$ & 30.91 & $C u-66$ & $5.1 \mathrm{~m}$ & 23 & 1039 & 93 & $833(2.5)$ & $N d-151(1042), G a-70(1042)$ \\
\hline $\begin{array}{l}\text { Dy } \\
\text { Eu }\end{array}$ & Eu-151 & 47.82 & $\mathrm{Eu}-152$ & $124 y$ & 5900 & 122 & 294 & $344(285), 964(162), 1112(154), 1408(229)$ & $\begin{array}{l}\text { Yb-169(118), Se-75(121), Eu-154(123), } \\
\text { Ba-131(124) }\end{array}$ \\
\hline $\mathrm{Fe}$ & $\mathrm{Fe}-58$ & 0.33 & $\mathrm{Fe}-59$ & 4so & 1.2 & 1099 & 560 & $192(25), 1292(440)$ & $T 0-160(1103)$ \\
\hline $\mathrm{HI}$ & $\mathrm{HI}-180$ & 35.24 & $\mathrm{Hf}-181$ & 430 & 10 & 482 & 810 & $133(400), 136(60), 346(130)$ & $\begin{array}{l}\text { Re-188(478), Eu-154(478), W-187(480), } \\
\text { Ir -192(485), Re-188(485), La-140(487) }\end{array}$ \\
\hline \multirow[t]{2}{*}{$\mathrm{Hg}$} & $\mathrm{Hg}-1 \%$ & Q. 146 & $\mathrm{Hg}-197$ & $65 \mathrm{~h}$ & 880 & $n$ & 180 & $191(10)$ & Pt-197(77) \\
\hline & $\mathrm{Hg}-202$ & 29.80 & $H_{j}-203$ & 46.60 & 4 & 279 & 820 & NONE & $\begin{array}{l}\mathrm{Hg}-197 \mathrm{~m}(279), \mathrm{Se}-75(280), 0 \mathrm{~s}-198(280) \\
\mathrm{Yb}-175(283), \mathrm{Ir}-192(283)\end{array}$ \\
\hline \multirow[t]{2}{*}{ In } & $\ln -113$ & 4.28 & $\ln -114 \mathrm{~m}$ & 5 as & 8 & 190 & 161 & $558051,725(35)$ & $\begin{array}{l}\text { Eu-154(188), Te-131m(189), Hg-197(191), } \\
\mathrm{Pt}-197(191), \mathrm{Fe}-59(192)\end{array}$ \\
\hline & $\ln -115$ & $\$ 5.72$ & $\ln -116 \mathrm{~m}$ & $54 m$ & 54 & 1097 & 530 & $\$ 17060), 1293(800)$ & NO SHORT-LIVED INTERERENCES \\
\hline k & $k-41$ & 6.88 & $k-42$ & $12.4 \mathrm{~h}$ & L.1 & 1525 & 180 & $313(1.8)$ & NONE \\
\hline La & La-139 & 99.911 & La-140 & 40. 2h & 29 & $15 \%$ & 970 & $328(210), 487(460), 816(240)$ & $\mathrm{Ga}-72(1596)$ \\
\hline Lu & $L U-176$ & 259 & Lu-177] & 6.70 & 2100 & 208 & 75 & $113(44)$ & $W-187(206), L u-177 \mathrm{~m}(208)$ \\
\hline $\mathrm{Mg}$ & $M g-26$ & 11.17 & $\mathrm{Mg}-27$ & $9.5 \mathrm{~m}$ & 0.03 & 1014 & 300 & $844(700)$ & Mo-101(1012), No-151(1016) \\
\hline $\mathrm{Mn}_{n}$ & $M n-55$ & 100 & $M n-56$ & $258 \mathrm{~h}$ & 3.3 & 847 & 990 & $1810(297), 2113(151)$ & $M g-27(844)$ \\
\hline $\mathrm{Na}$ & $\mathrm{Na}-2 \mathrm{z}$ & 100 & $\mathrm{Na}-24$ & $15.0 \mathrm{n}$ & Q.13 & 1369 & 1000 & $2754(1000)$ & NONE \\
\hline \multirow[t]{2}{*}{$\mathrm{Ni}$} & $\mathrm{Ni}-58$ & 67.88 & $\mathrm{C}_{0}-58$ & 710 & 0.1 & 810 & 990 & $511(300)$ & Сa-47(807). Eu-152(810) \\
\hline & $\mathrm{Ni}-64$ & 1.08 & $\mathrm{Ni}-65$ & $2.56 \mathrm{~h}$ & 1.5 & 1482 & 836 & $366(150), 115(547)$ & $\mathrm{Ge}-77(1478), \mathrm{Mo}-93 \mathrm{~m}(1479), \mathrm{Nd}-151(1486)$ \\
\hline$R D$ & $\mathrm{Rb}-8 \mathrm{~S}$ & 7215 & $\mathrm{Rb}-96$ & 18.70 & 0.9 & 1076 & 88 & NONE & NONE \\
\hline Sb & $5 b-121$ & 57.25 & Sb-122 & 2.80 & 6 & 564 & 663 & $692 B 31$ & As $-76(559), C s-134(563)$, Ea-152(566) \\
\hline \multirow{2}{*}{$\begin{array}{l}\text { Sin } \\
\text { Sr }\end{array}$} & $S \bar{m}-152$ & 26.72 & $3 m-153$ & $47 \mathrm{~h}$ & 210 & 103 & 270 & NO MAJOR & $\mathrm{Ta}-1821100 \mathrm{i}$ \\
\hline & $5 r-84$ & 0.56 & $5 r-85$ & 650 & a. & 514 & 100 & NO MAJOR & $\begin{array}{l}\text { As-76(510), La-140(511), W- } 187(512) \text {, } \\
\text { B }^{+} \text {EMI TIERS }\end{array}$ \\
\hline Ta & Ta-181 & 99.988 & Тa-182 & 1150 & 21 & 1221 & 278 & $\begin{array}{l}100(142), 1121(350), 1189(166), \\
1230(117)\end{array}$ & Ir -1941(1219), As $-75(1220)$ \\
\hline \multirow{2}{*}{$\begin{array}{l}\text { To } \\
T_{h}^{(a)}\end{array}$} & Tb-159 & 160 & $T b-160$ & $72 \mathrm{~d}$ & 46 & 879 & 318 & $298(263), 962(126), \% 6(276), 1178(166)$ & $W-187(879), \mathrm{Ce}-143(880)$ \\
\hline & Ih-žz & 100 & $\begin{array}{l}\mathrm{Th}-233 \\
\mathrm{~Pa}-233\end{array}$ & $221 \mathrm{~m}$ & 7.4 & $\overline{312}$ & 440 & NO MAJOR & $\mathrm{Nd}-147(319 ;, \mathrm{Ir}-192(317), \mathrm{Cr}-51020)$ \\
\hline Ti & $T i-50$ & 5.34 & $1 i-51$ & $5.80 \mathrm{~m}$ & 0.14 & 320 & 955 & $608(15) .928(45)$ & 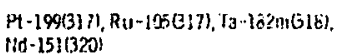 \\
\hline U(b) & U-238 & 99.27 & $\begin{array}{l}\text { U-239 } \\
N p-399\end{array}$ & $\begin{array}{l}23.5 \mathrm{in} \\
235 \mathrm{~d}\end{array}$ & 27 & $\ddot{228}$ & 120 & $106(230), 209(40), 278(140)$ & $\begin{array}{l}\text { Gd-159(226), Lu-177m(228), fa-182(229), } \\
C_{e}-143(232)\end{array}$ \\
\hline \multirow{4}{*}{$\begin{array}{l}V \\
Y b \\
Z n\end{array}$} & $V-51$ & 99.76 & $v-52$ & $3.77 \mathrm{~m}$ & 4.9 & 1434 & 990 & NONE & Ba-139(1430) \\
\hline & $Y_{b}-176$ & $12 \pi$ & $Y b-177$ & L.9 & 7 & 150 & 168 & $121(17), 1079(47), 1120(10), 1241126)$ & Te-13!(150),Kr-85m(15)),Si - $85 m(15 !)$ \\
\hline & $2 n-64$ & 48.89 & $2 n-65$ & $243 d$ & 0.46 & 1116 & 506 & NO MAJOR & $\begin{array}{l}\text { Te-129m(1112),EU-152(1)12),Ja-182(1)13), } \\
\text { m-160(1115) Sc-46(1121) }\end{array}$ \\
\hline & $2 n-68$ & 18.57 & $2 n-69$ & $14 h$ & Q.1 & 439 & 950 & NONE & Nd-147(440), Os - 193441$)$ \\
\hline
\end{tabular}

(a) THORIUIM IS MEA SURED BY COUNTING THE 27 DAY $233_{\mathrm{Pa}}$ DAUGHTER OF $233_{\mathrm{Th}}$

b) URANIUM IS MEASUREO BY COUNTING THE 2.35 DAY 239 N OAUGHTER OF $39 \mathrm{~J}$ 